
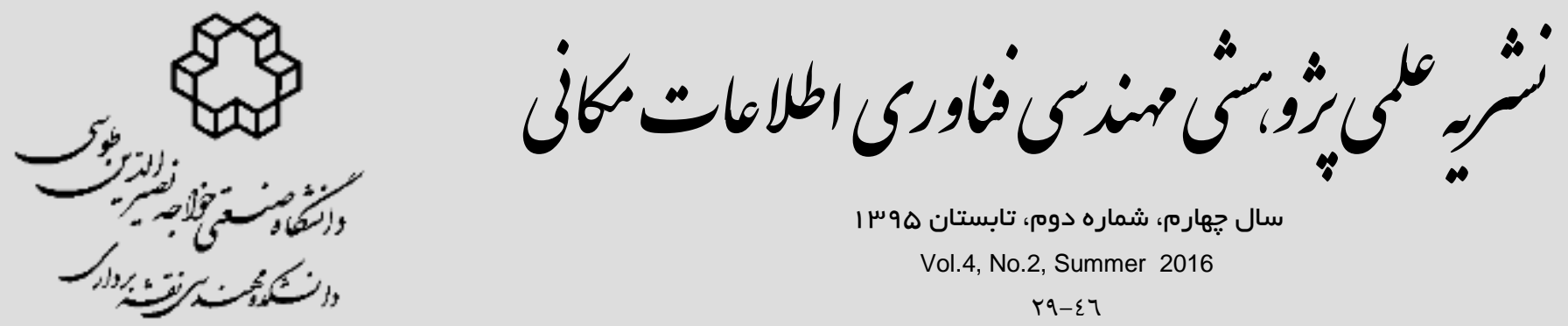

سال جهارم، شماره دوم، تابستان هوس

Vol.4, No.2, Summer 2016

rq- \&

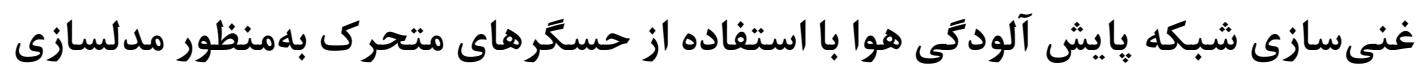

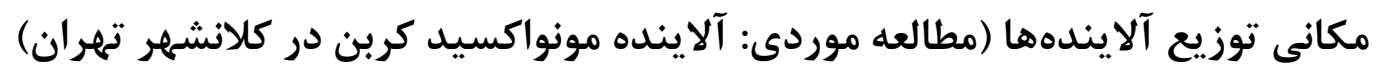

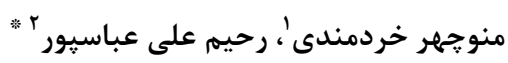

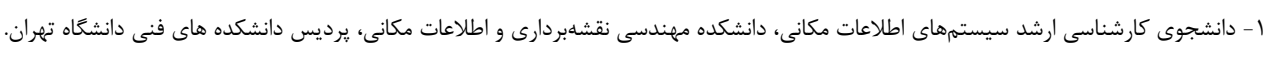

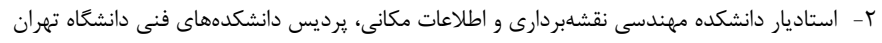

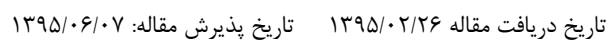

جكيده

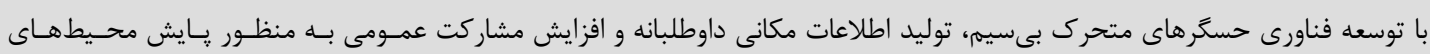

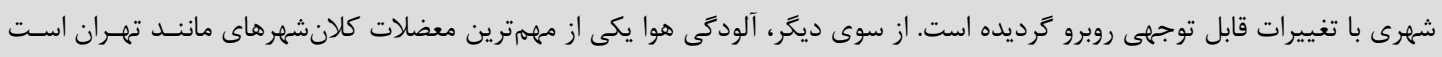

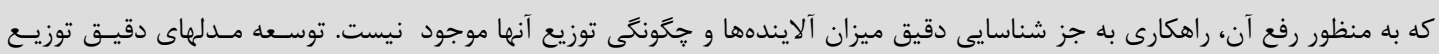

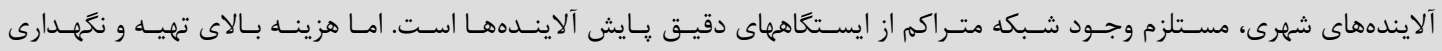

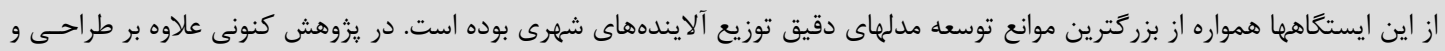

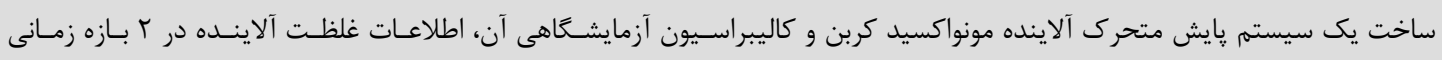

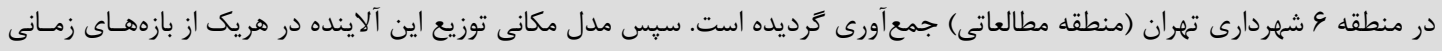

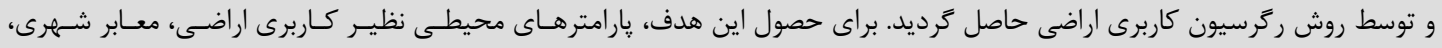

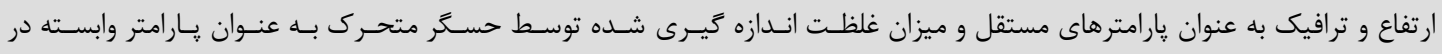

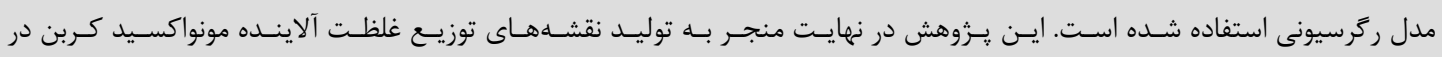

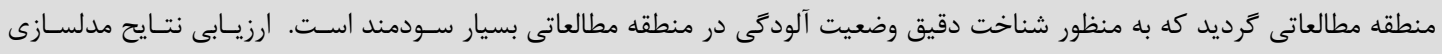

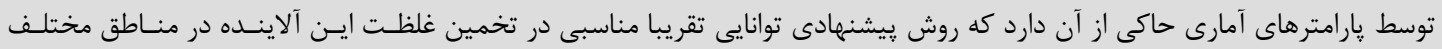
شهرى دارد. وازههاى كليدى: اطلاعات مكانى داوطلبانه، حسگرهاى متحرى يايش آلايندهاى هوا، بِهنهبندى، ركرسيون كاربرى اراضى.

* نويسنده مكاتبه كننده: : تهر ان، امير آباد شمالى، دانشكده فنى، دانشكده مهندسى نقشهبردارى و اطلاعات مكانى تلفن: 
عنايت به بِيشرفتهاى اخير در حوزه ارتباطات بىسـيمه

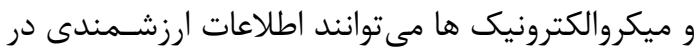

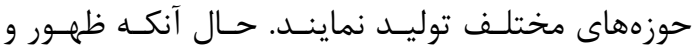

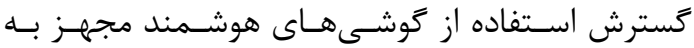

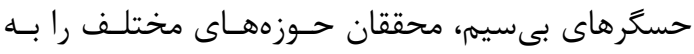

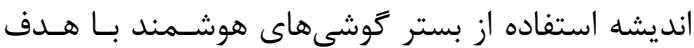
بايش محيط رهنمون ساخت. كاربردهاى نوعى اين نوع

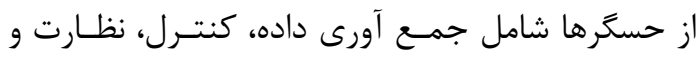

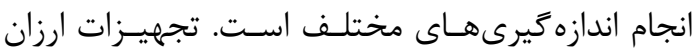

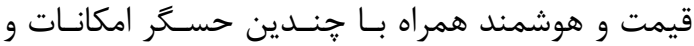
فرصتهاى بسيارى را در پايش و كنترل شهرها، خانههـا و حتى محيطهاى پيرامون در اختيارمان قرار مى دهند.

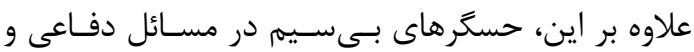
نظامى، مانند بررسى امكانات دشمن و نظارت بر اعمـال

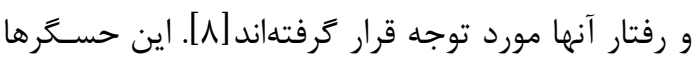
در محيط مستقر شده و دادههاى مختلفى از قبيل دمـا،

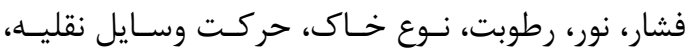

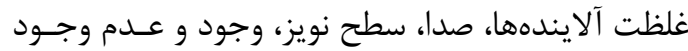

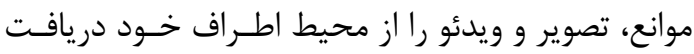

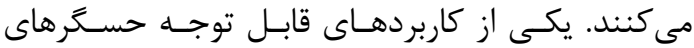

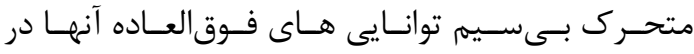

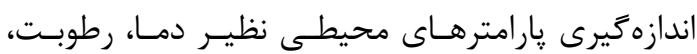

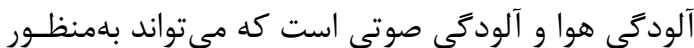

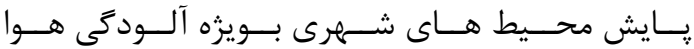

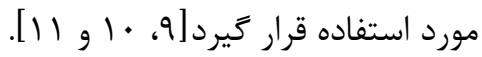

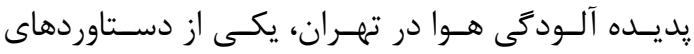

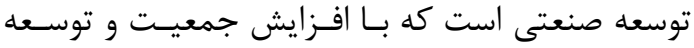

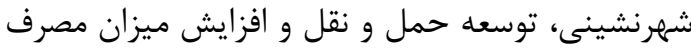

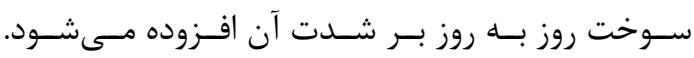
در حال حاضر مهمترين معضل زيست محيطى شـهر

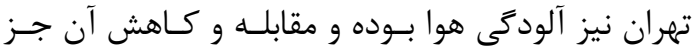

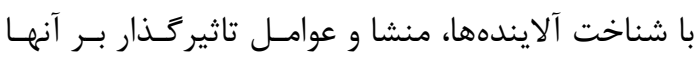

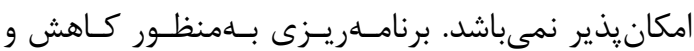

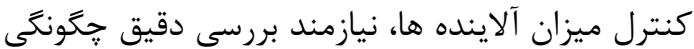

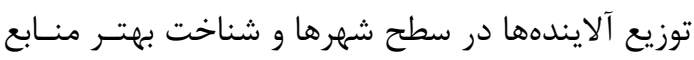

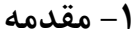

بى شك مشاركت كاربران در اتخاذ تصميماتى كه قـرار

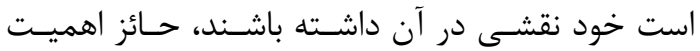
است. جامعه شناسان معتقدند افرادى كه در ارتبـاط بـا

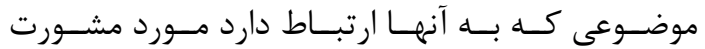
قرارنكرفته باشند، حتى اكر تصميمات در آينده مزايايى

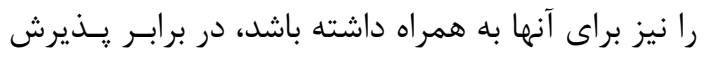

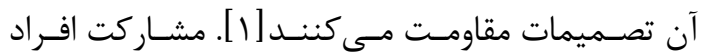
غيرخبره در يروزه هاى مرتبط با اطلاعات مكانى توسط

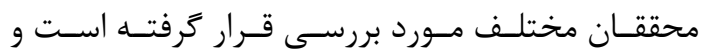

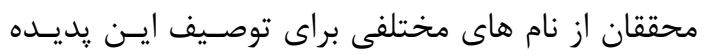
استفاده كرده است كه از ميان آنها براى نمونه مى آنـان توان

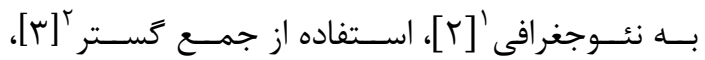

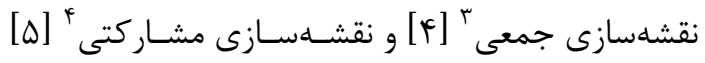
اشاره كرد. امـا در ايـن ميـان مفهـوم اطلاعـات مكـانى

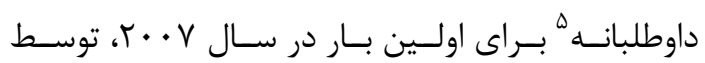

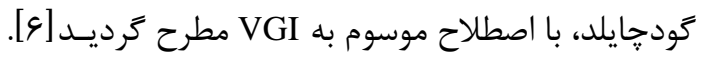

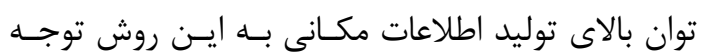
محققان حوزه هاى متعـددى را بــه خـود جلـب نمـود. براى تبيين ارزش و اهميت داده هاى مكانى داوطلبانسه

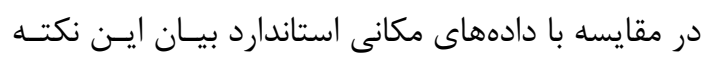
كه VGI نه تنها ارزان ترين بلكه حتى در مواردى تنهـا

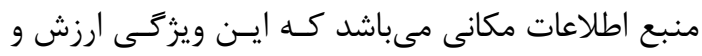

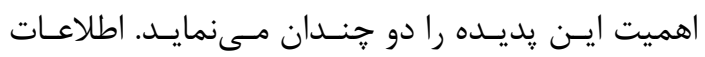
جمع آورى شده در زلزله زانويسه سـال • • ب در كشــور

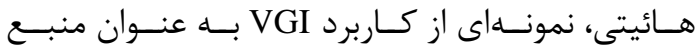

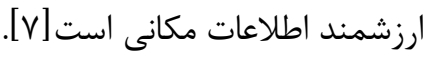

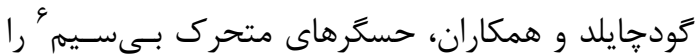

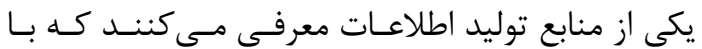

${ }^{1}$ Neogeography

${ }^{2}$ Crowdsourcing

${ }^{3}$ Collaborative mapping

${ }^{4}$ Participatory mapping

${ }^{5}$ Volunteered Geographic Information (VGI)

${ }^{6}$ Wireless Mobile Sensors 
آلايندهها از طريق حسگرهاى بسىسـيم در بسـتر VGI

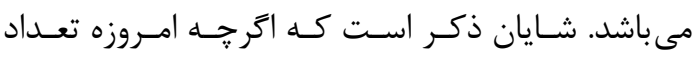
محدودى از گَوشىهاى هوشمند مجهز به حسكَ ريـايش

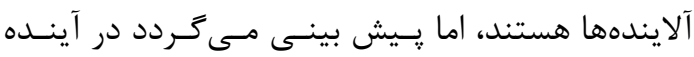

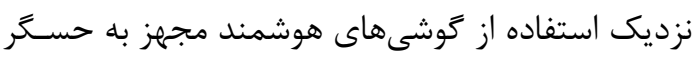
يايش آلايندهها امرى عادى گردد.

در اين يزوهش يس از طراحسى و سـاخت يـك حســر

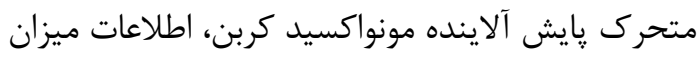

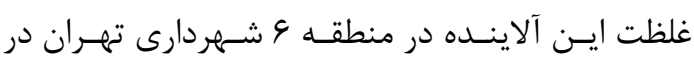
r دوره زمانى مختلف در طى r روز جمع آورى گرديد.

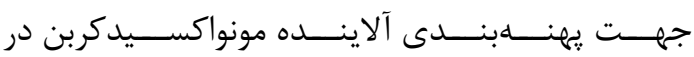
منطقه مطالعاتى روش رگرسيون كاربرى اراضى استفاده

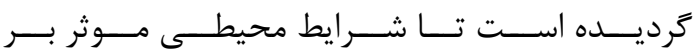
غلظت اين آلاينده نيز شناسايى شوند.

\section{r- بيشينه تحقيق}

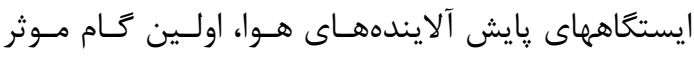

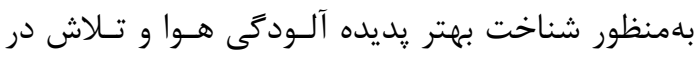
جهت حل اين مشكل در كلانشـهرها مسىباشـد. اولـين

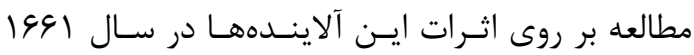

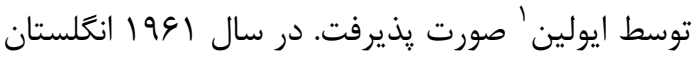

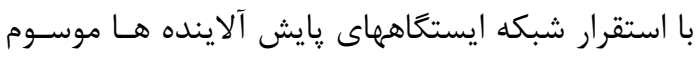

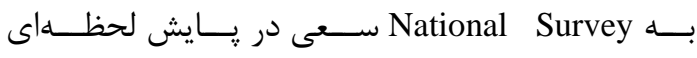

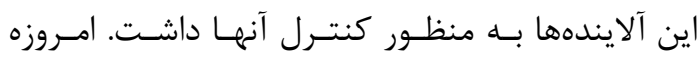

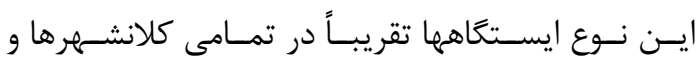

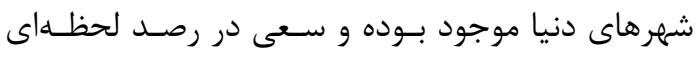

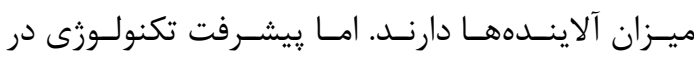

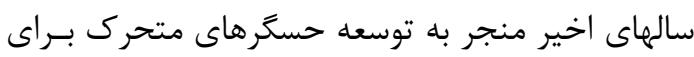

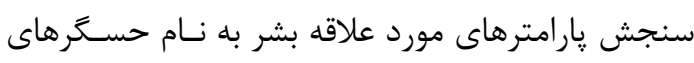

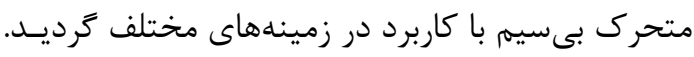

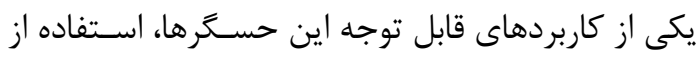
آنها به منظور رايش محيطى بويزه آلايندههاى محيطى آنى

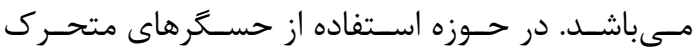

\footnotetext{
${ }^{1}$ Evelyn
}

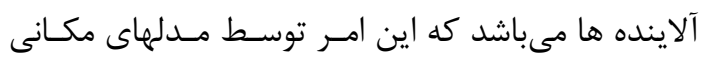

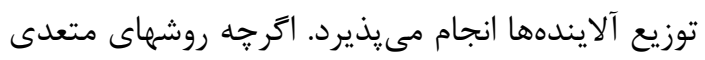

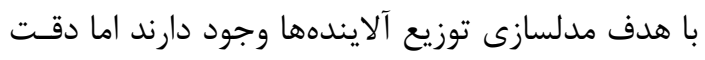

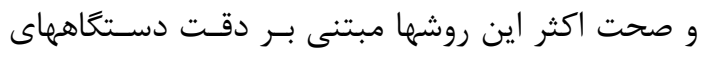

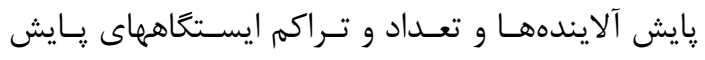

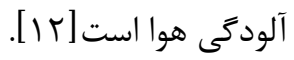

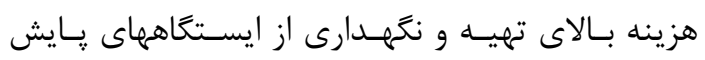

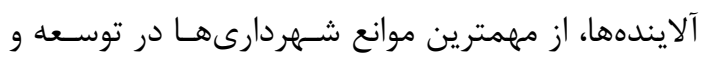

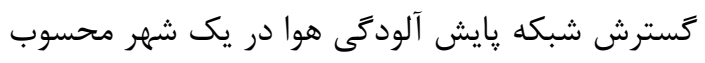

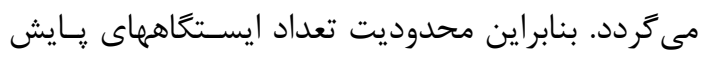

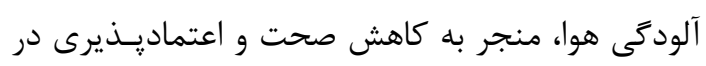

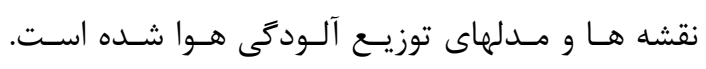
از ديخرسو آلودگى هوا به دليل شرايط دينـاميكى هــــوا،

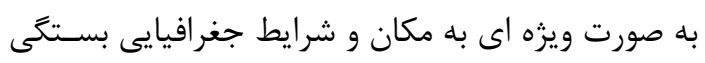

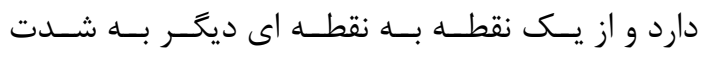

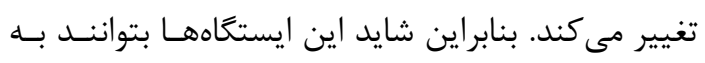

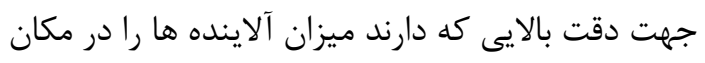

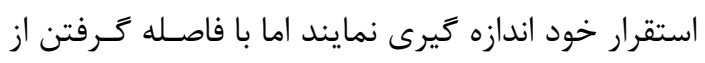

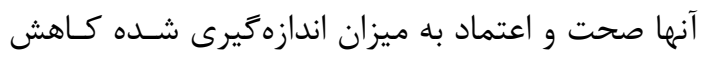

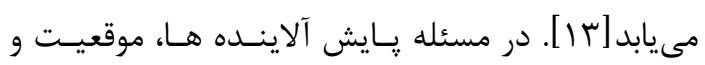

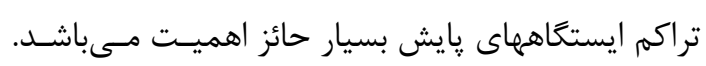

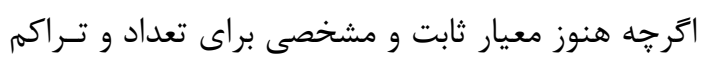

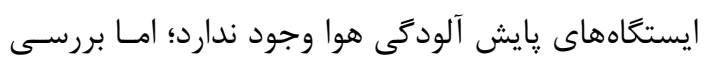

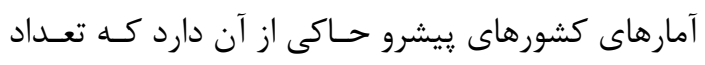

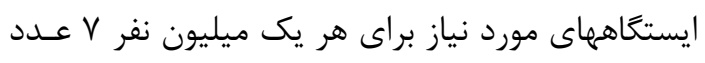

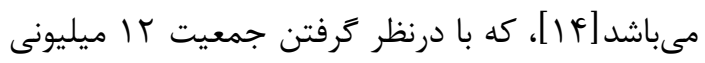
ميليونى

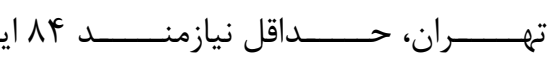
ضايش آلايندها مى ضياشيم

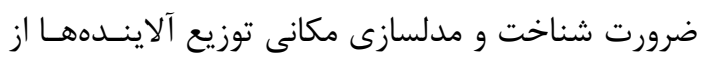

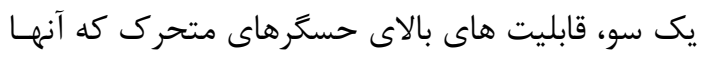

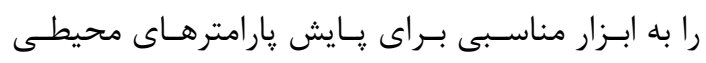

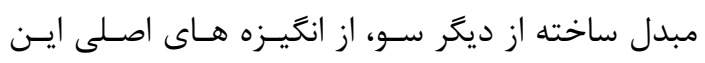

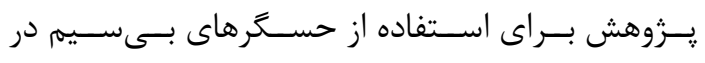

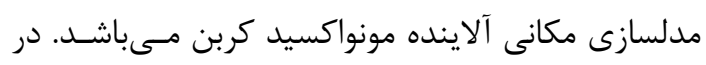
واقع يكى از اهداف اين تحقيق غنى سازى شبكه پايش 
هوا مدل ركرسيون كـاربرى اراضىى هـ (LUR)مسىباشـد.

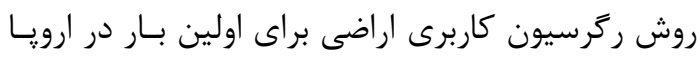

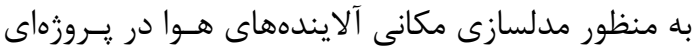
با نام تغييرات كوجك محلى در سلامت و كيفيـت هـوا

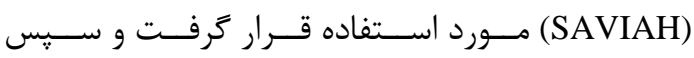

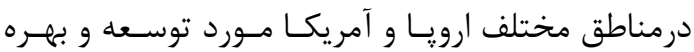

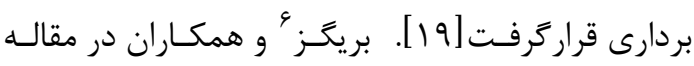

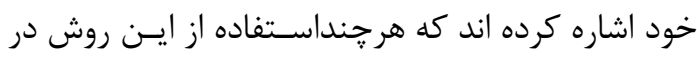

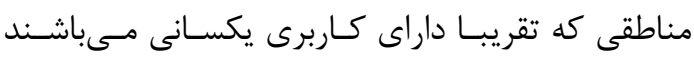

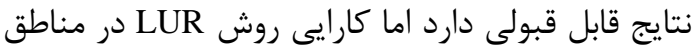

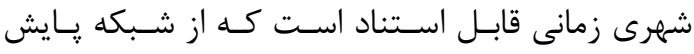

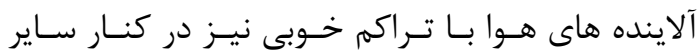

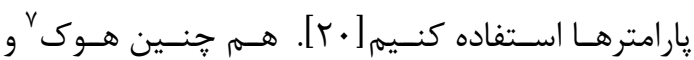

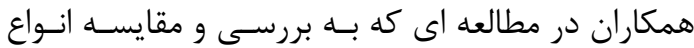

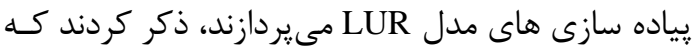

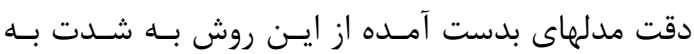
تعداد و مكان قرار كيرى ايستكاههاى يايش آلايندههـا و

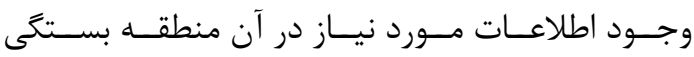
[1

متاسـفانه مطالعـات انـدكى بـهـ اسـتفاده از حســرهاى

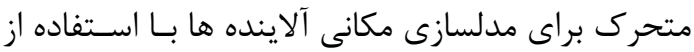

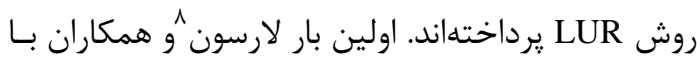
استفاده از يك حسكر بايش متحرك، سعى در افز إيش

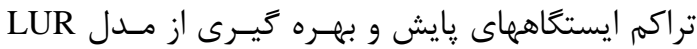

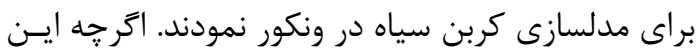

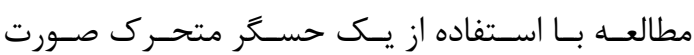
يذيرفته است اما صرفا با استقرار يك حســر يـايش در نقاط مختلف منطقه مطالعاتى، تراكم اطلاعات يايش در منطقه مطالعاتى بالابرده شده و مدل مكانى بـا اسـتفاده

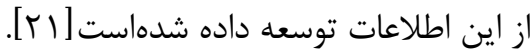
بررسىها حاكى از آن است كـه اسـتفاده از حســرهاى

\footnotetext{
${ }^{5}$ Land Use Regression
}

${ }^{6}$ Briggs

${ }^{7}$ Hoak

${ }^{8}$ Larson
بىسيم به منظور رايش آلايندههاى محيطى، نخسـتين

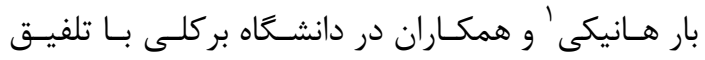

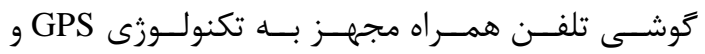

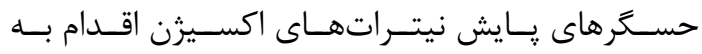
يايش لحظهاى اين آلاينده ها درمسيرهاى مختلف شهر

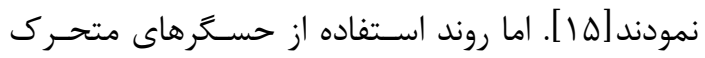

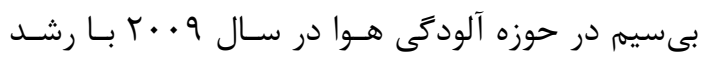
قابل توجهى روبرو گرديد. جوى 'َو همكاران با طراحسى و توسعه سيستمهاى يايش لحظهاى انواع آلاينـدههــاى

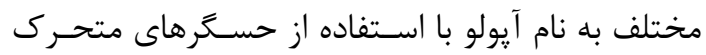

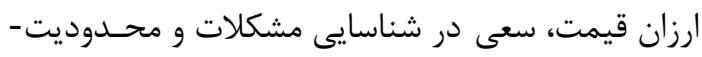

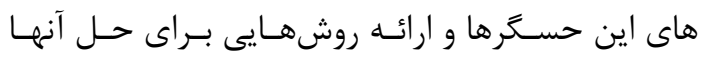

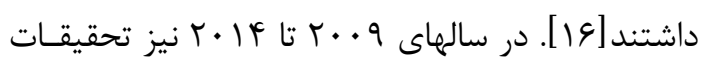

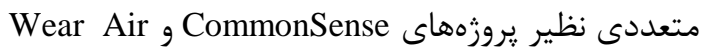
انجام كرديد، كـهـ هـدف اصـلى تمـامى ايسن تحقيقــات

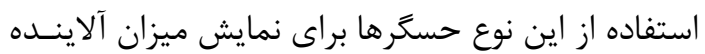

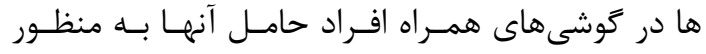

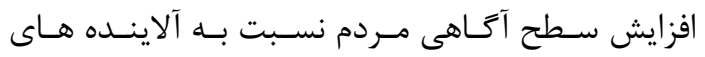

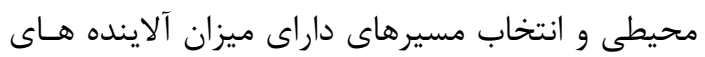

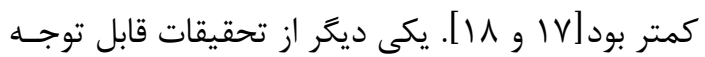

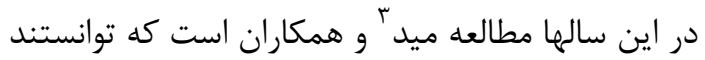

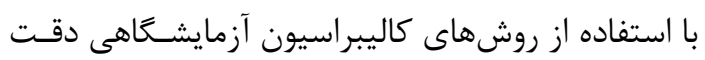
حسگرهاى متحرك تكنولوزى الكتروشـيميايى (بيشـتر

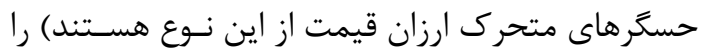
به دقت هـاى قابـل قبـول قسـمت در ميليـارد ${ }^{r}$

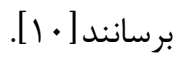
به منظور مدلسازى مكانى ميزان غلظت آلاينـده هـا يـا

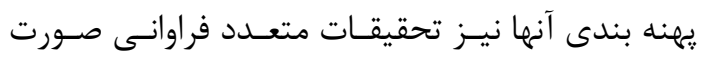

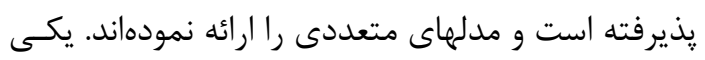

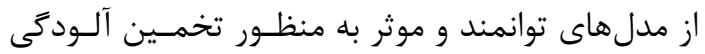

\footnotetext{
${ }^{1}$ Honickey

${ }^{2}$ Choi

${ }^{3}$ Mead

${ }^{4}$ Part Per Bilion
} 


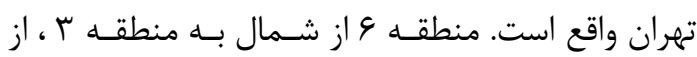

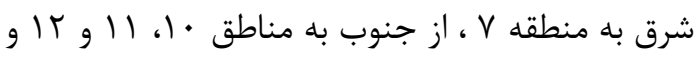

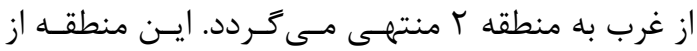

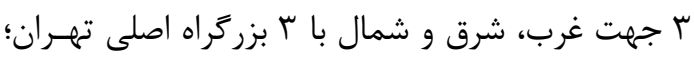

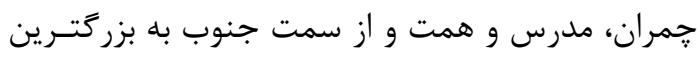

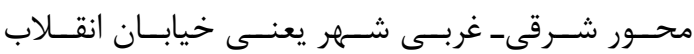

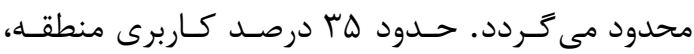

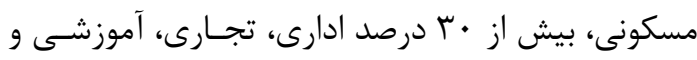

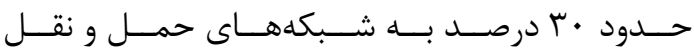

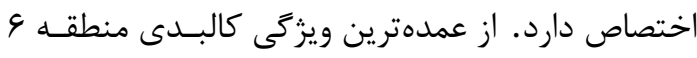

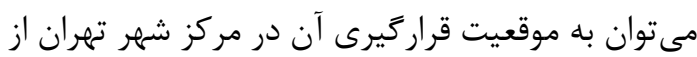

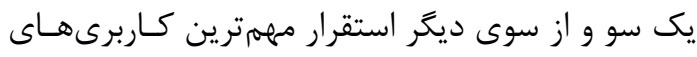

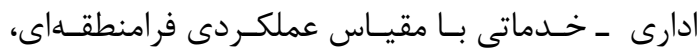
شهرى و حتى ملى در آن اشاره كـرد. تـراكم مسـكونى دمانى

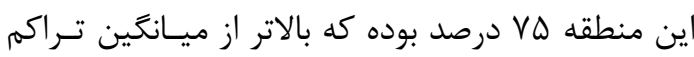

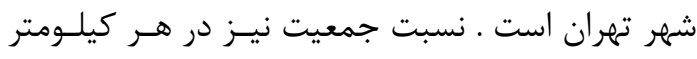

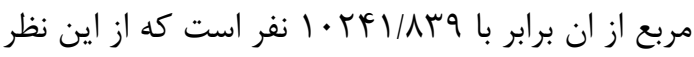

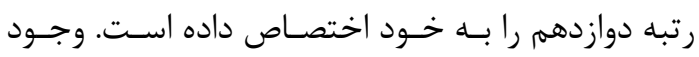
بيش از عץ بيمارستان و مركز درمـانى از جملـه مركـز

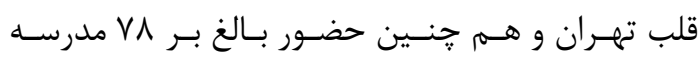

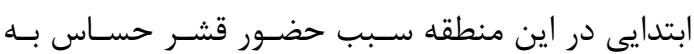

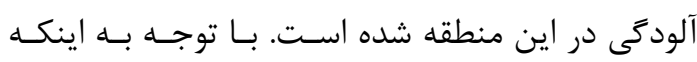

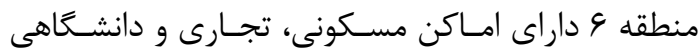

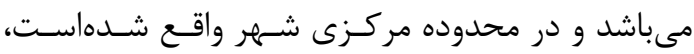

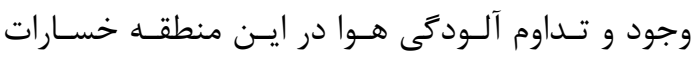

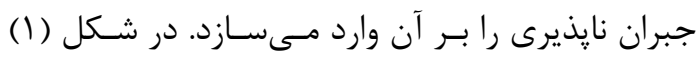

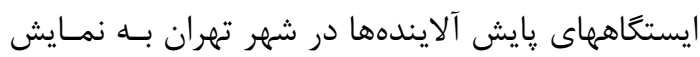

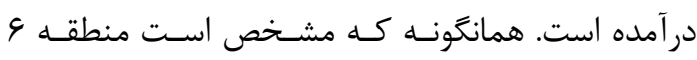

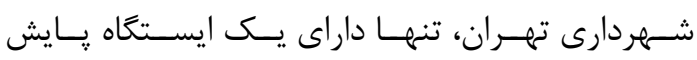
آلاينده مونواكسيد كربن مى تهباشد.
متحرى در مدلسازى آلايندهها مسى توانـد نتـايج جالـب

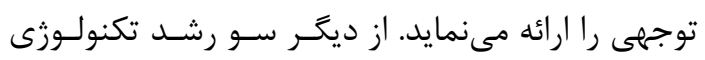

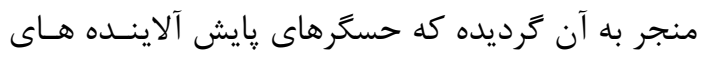

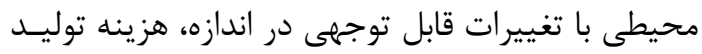

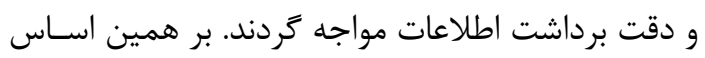

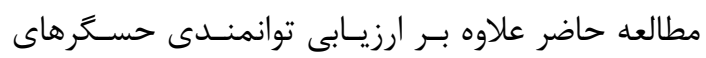

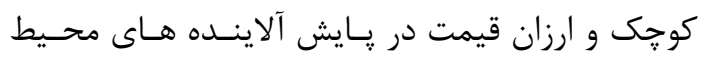
شهرى، توانايى آنها را در مدلسازى مكانى توزيع آلاينده

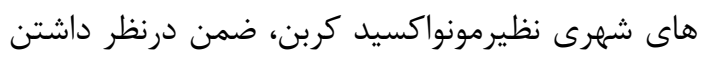

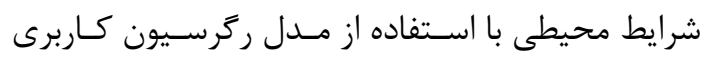

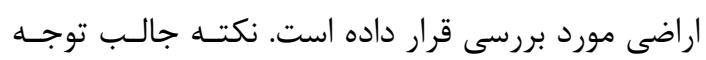

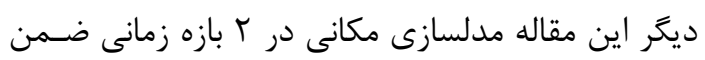

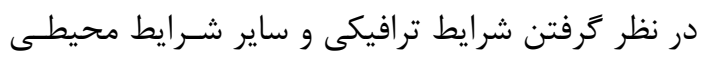
موثر مىباشد.

\section{ب - - منطقه مورد مطالعه}

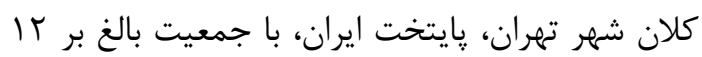

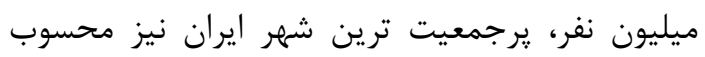

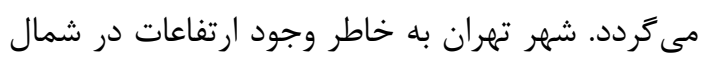
و شرق و وجود بافت قديمى شهرى، رشد بـى رويه

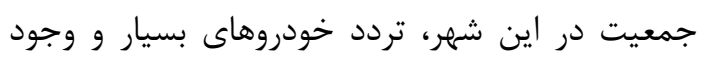

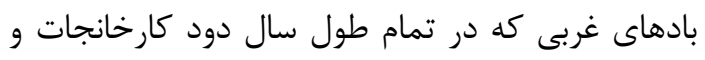
ساير عوامل آلوده كننده را به سطح شهر تهران سان داد

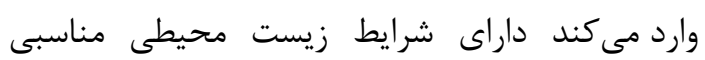
نمىباشد.

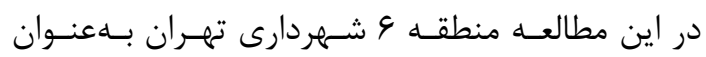

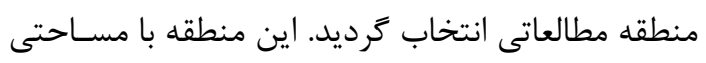

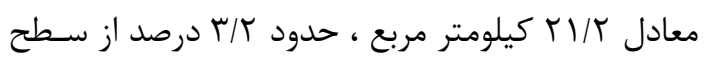

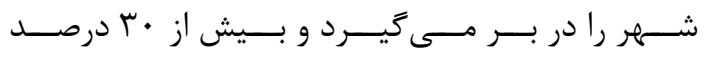

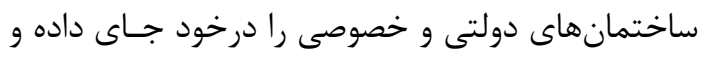

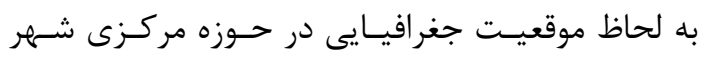




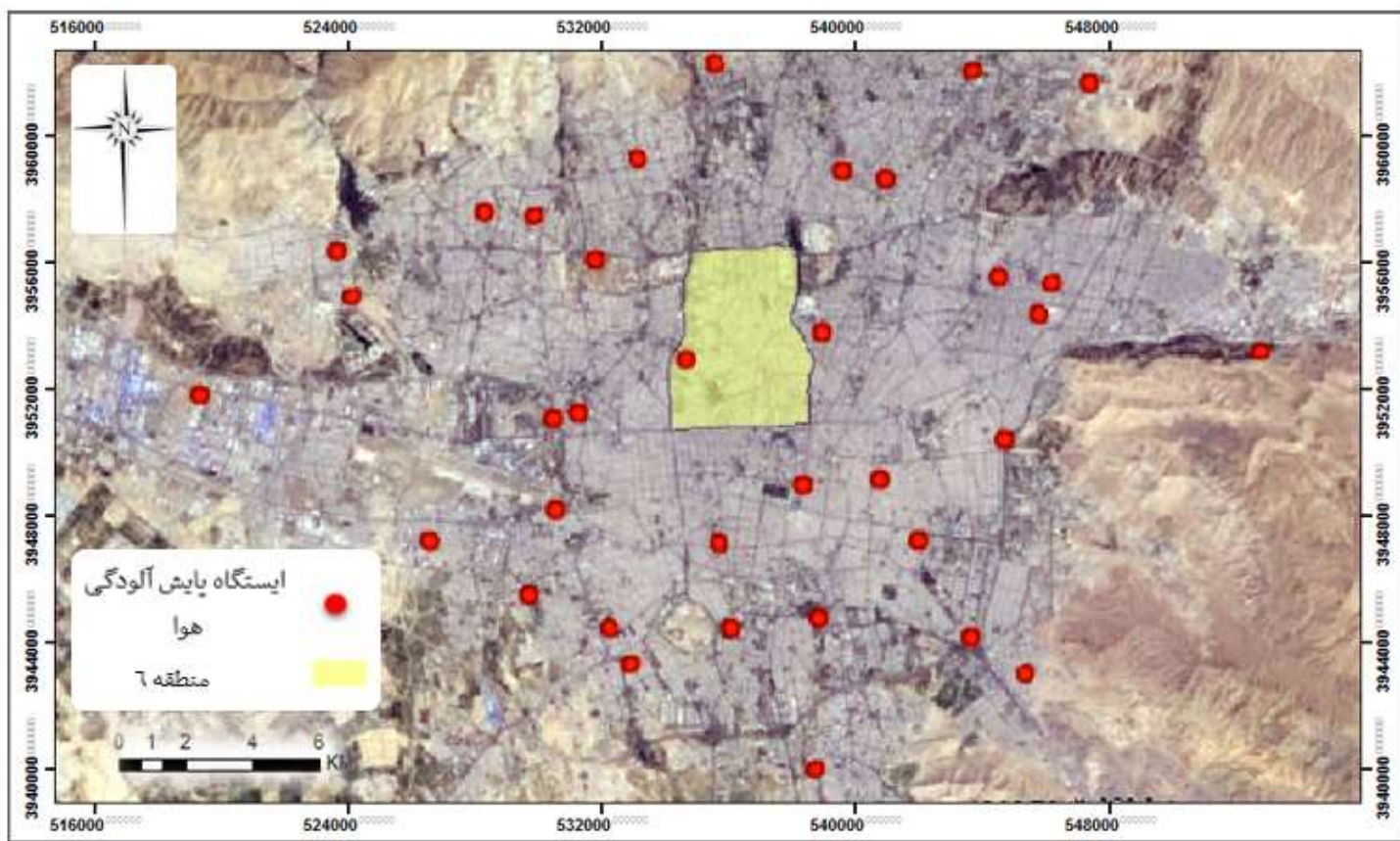

شكل ا: يراكندكى ايستعاههاى پايش آلاينده هاى هوا در تهران

$$
\text { قرار گرفته است. }
$$

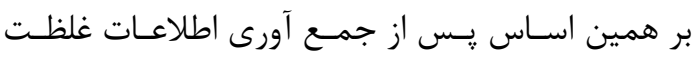

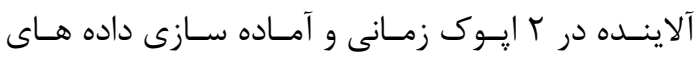

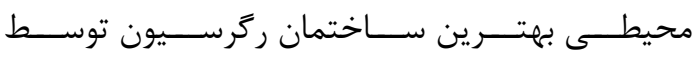

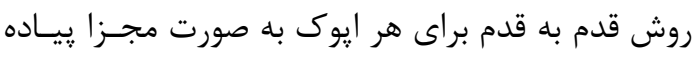

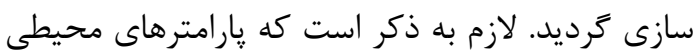

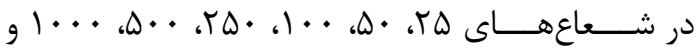

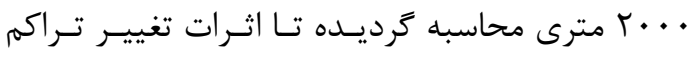

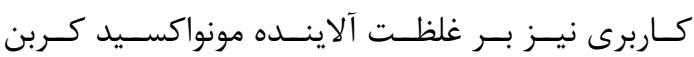

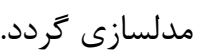
بلهنظور برآورد غلظت و يهرده بندى ميـزان آلاينـده در

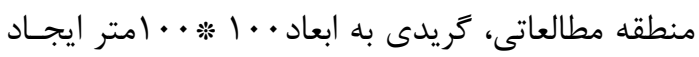

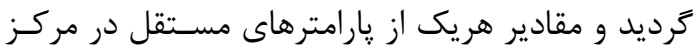

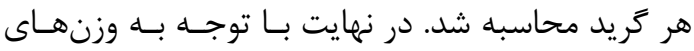

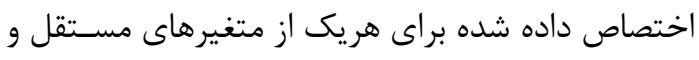
مقادير يارامتر مستقل، ميـزان غلظـت مونواكسـيدكربن محاسبه و رويه مد نظر بر روى منطقه مطالعاتى برازش

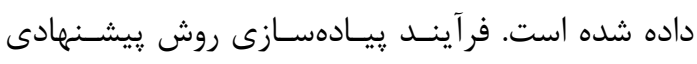
بهصورت خلاصه در شكل (Y) نمايش داده شدهاست.

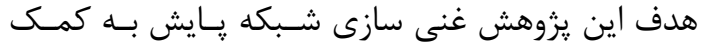

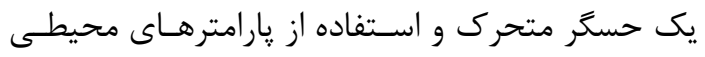

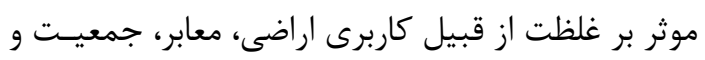

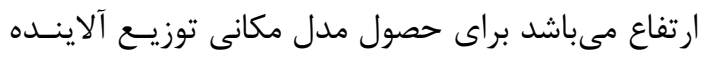

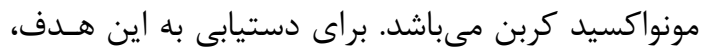

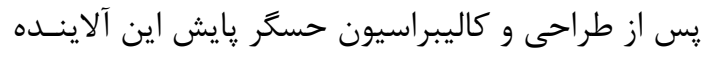

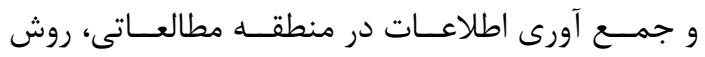

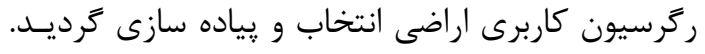

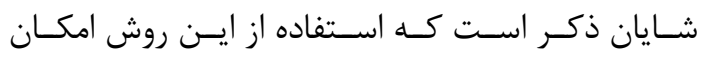

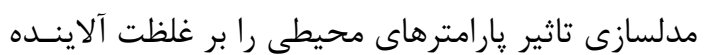

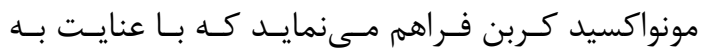
تغييرات شديد كاربرى اراضى مناطق شهرى استفاده از

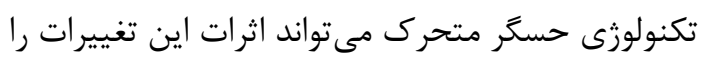

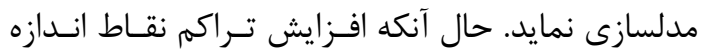

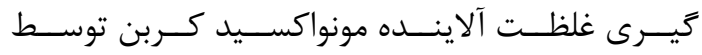

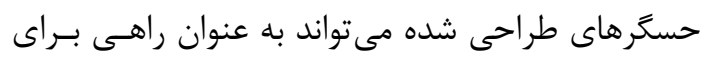
افزايش دقت اين روش در مدلسازى غلظت آلاينـده هـا

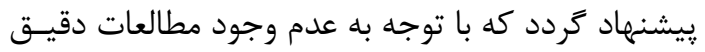

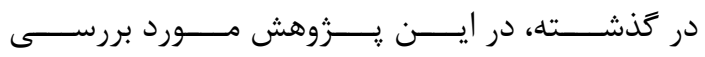




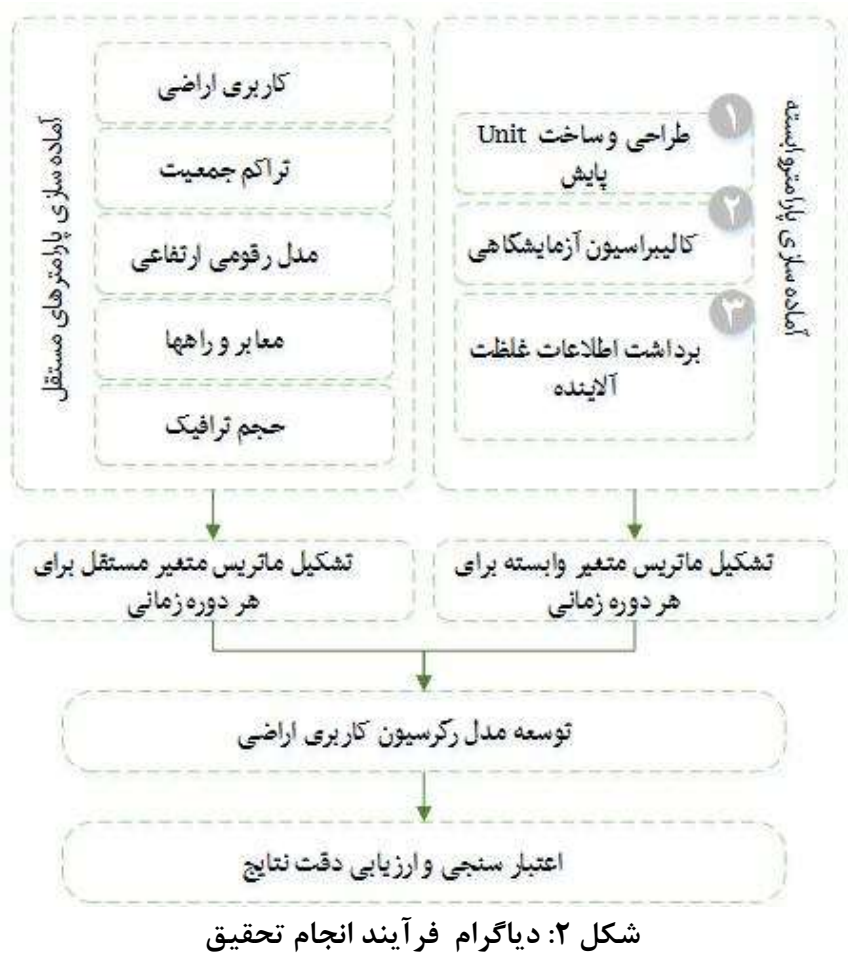

كـربن كـه شـامل حسـرَ آلاينـده مونواكسـيدكربن بـا

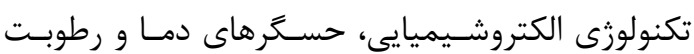

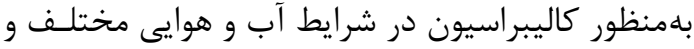

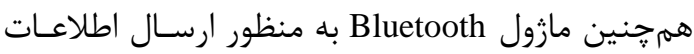

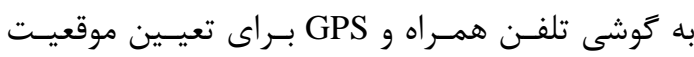

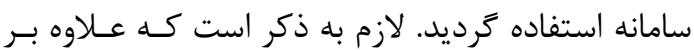

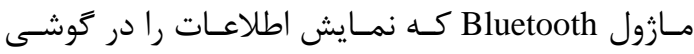

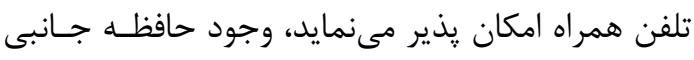

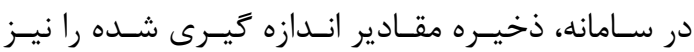

$$
\text { فراهم نمودهاست. }
$$

$$
\text { كاليبراسيون حسگر }
$$

در اين تحقيق به منظور كاليبراسيون سيستم از رويكرد

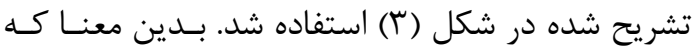

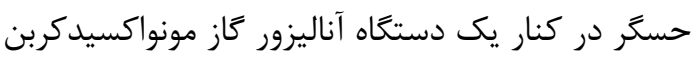
قــرار كرفتـه و (environment 12M CO Analyzer)

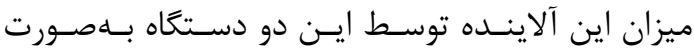

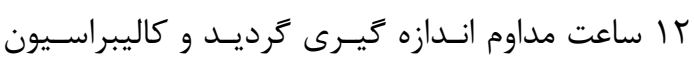
حسكر متحرك با استفاده از اطلاعات دسـتًاه آنـاليزور

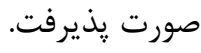

F - آ- آمادهسازى دادههاى مورد نياز به منظور مدلسازى به روش رَّرسيون كـاربرى اراضى لـ از يارامترهاى وابسته و مستقل استفاده كرديـد. مقــادير

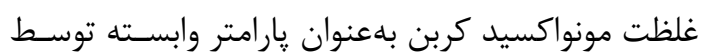
سيستم پايش طراحى شـده جمـع آورى كرديـــ و داده هاى مستقل (يارامترها محيطى موثر) از منابع مختلـف إنف

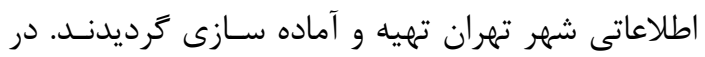

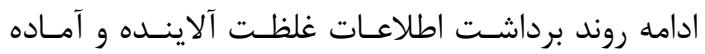
سازى يارامترهاى محيطى تشريح شدهاند. F-1-1- اطلاعات غلظت آلاينده مونواكسيد كربن

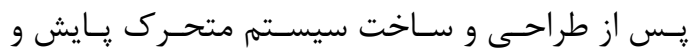

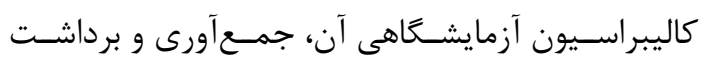

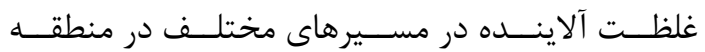

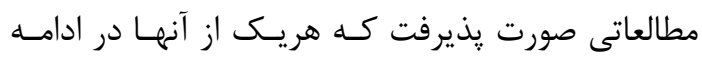

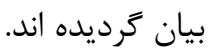

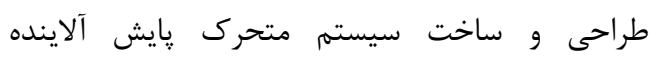

$$
\text { مونواكسيد كربن }
$$

در اين يزوهش از سامانه سـنجش آلاينـده مونواكسـيد 


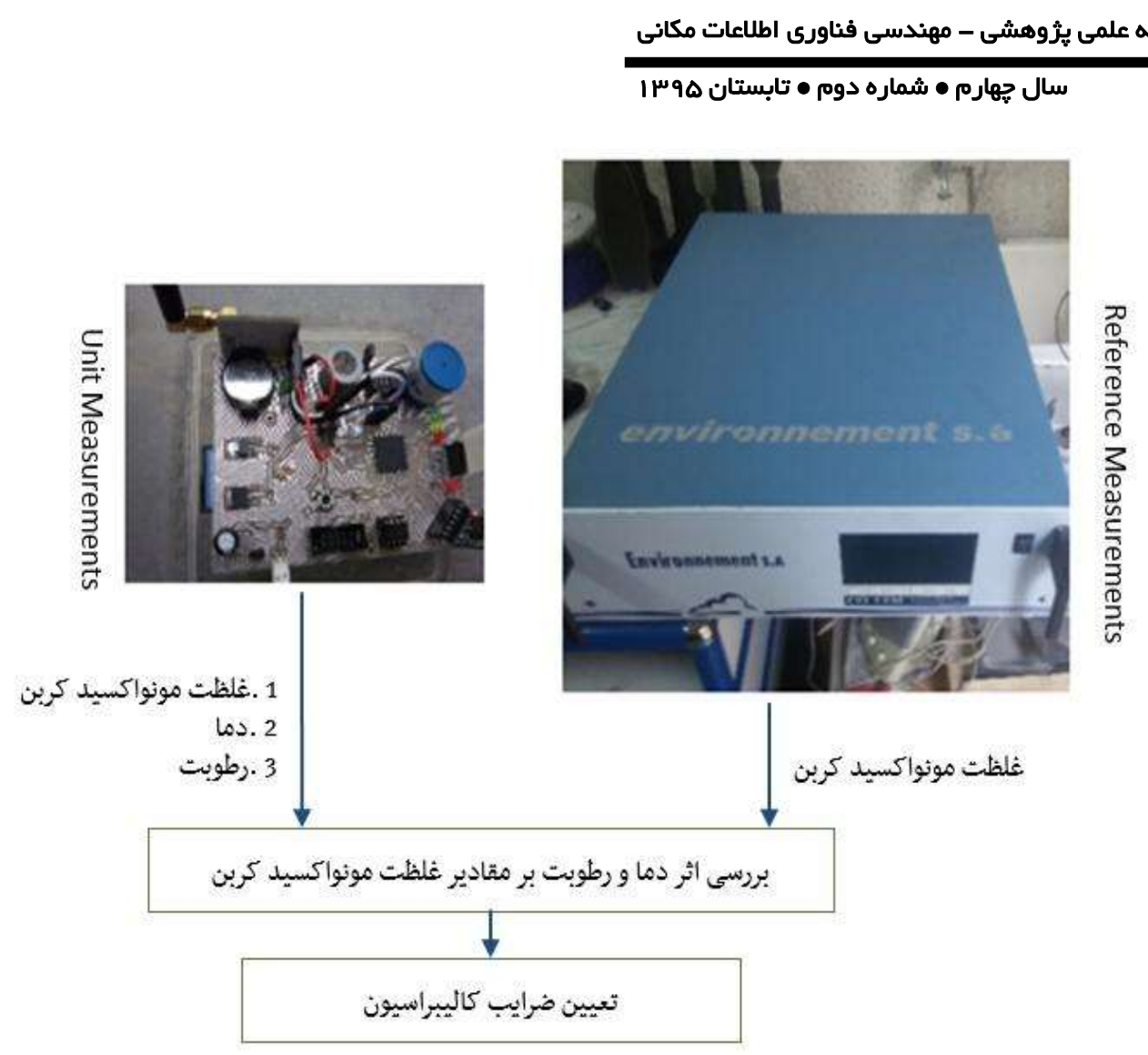

شكل ץ: فر آيند كاليبراسيون سيستم طراحى شده

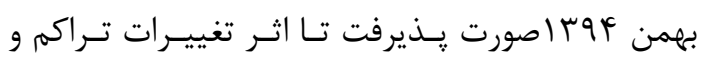

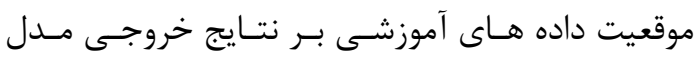

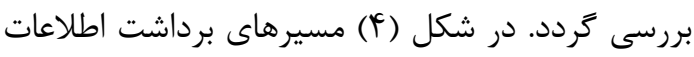

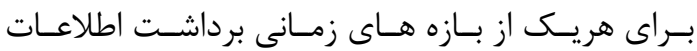
بلمنمايش در آمده است.

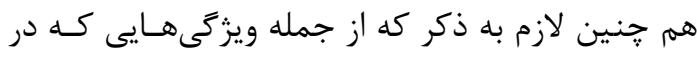
طراحى اوليه اين حسكر مــد نظـر بـود، توانـايى تغييـر

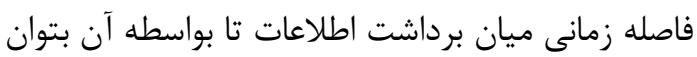

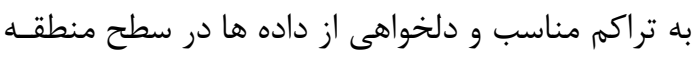

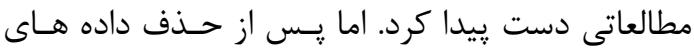
يرت و هم קنين حذف داده هاى با دقت مكـانى يـايين

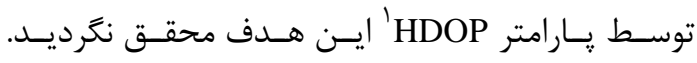
بر همين اساس קِ از حذف تمامى داده هـاى يـرت

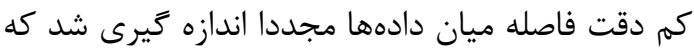

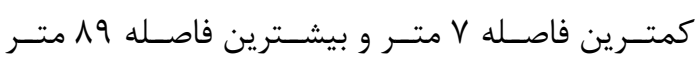

\footnotetext{
${ }^{1}$ Horizontal Dilution OF Precision
}

بلمنظور انجام كاليبراسيون هريك از يارامترهاى دمـا و و

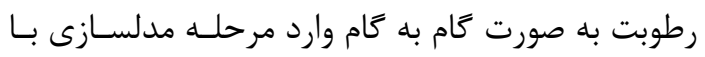

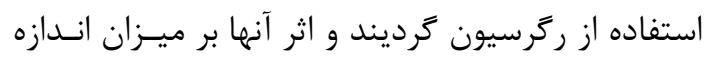

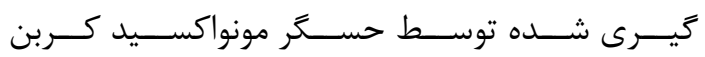

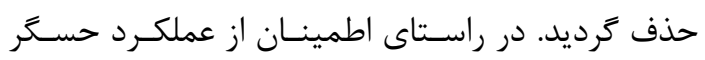

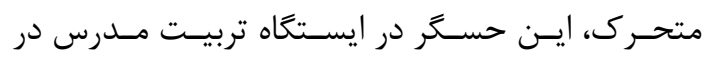

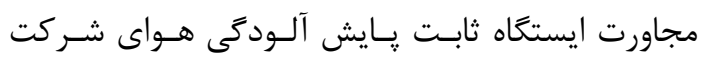

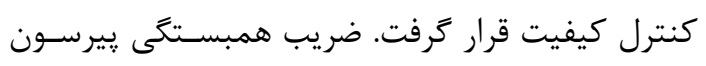

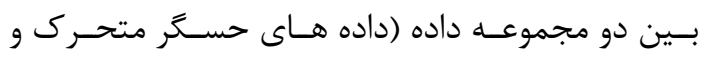
دادههاى ايستخاه ثابت) ميزان AF • • استحصال ترديد.

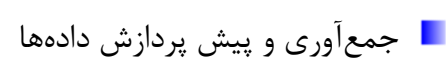

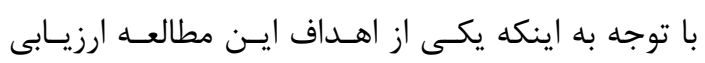

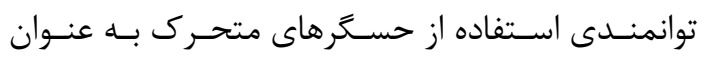
بسترى براى جمع آورى اطلاعات مكانى داوطلبانه است.

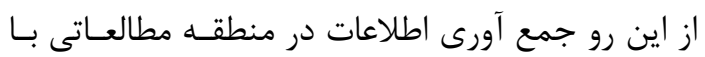

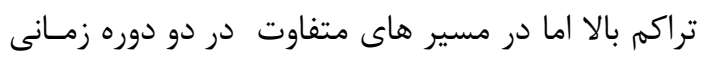

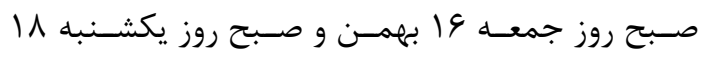


غنى سـازى شـبكه يـايش آلـودكَى هـوا بـا اسـتفاده از....

منوجهر خردمندى، رحيم على عباسيور

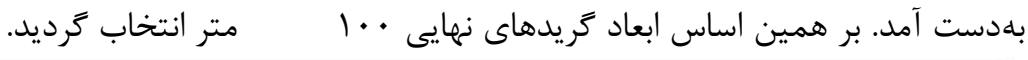

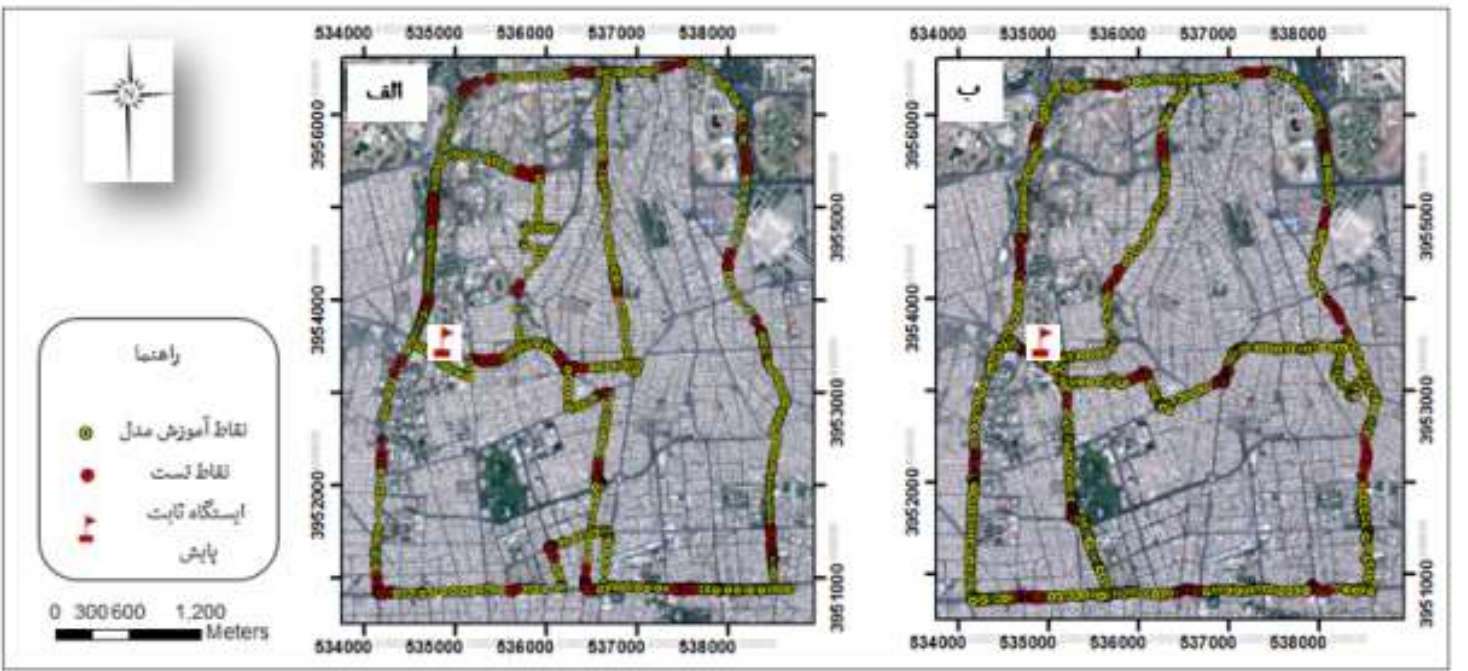

شكل f : مسير هاى برداشت غلظت آلاينده درمنطقه مطالعاتى الف) صبح روز جمعه ب) صبح روز يكشنبه

حذف دادههاى يرت توسط تست كراب'، تسـت نرمـال

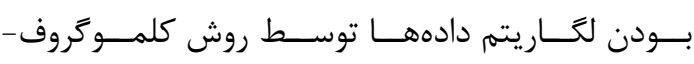

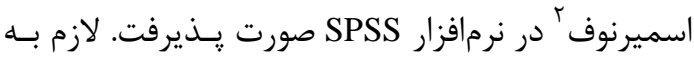
ذكر است كه به دليل فراوانى اندك مقادير غلظـت بـالا در محيطهاى شهرى، اكثريـت مطالعـات يِيشــين نيـز،

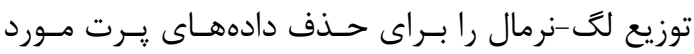

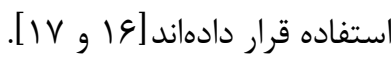

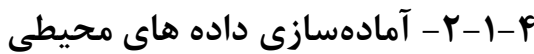

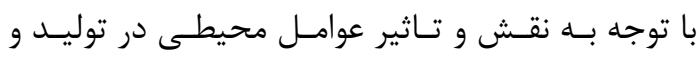

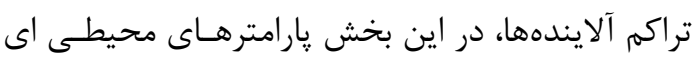

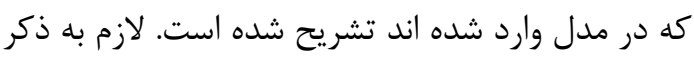

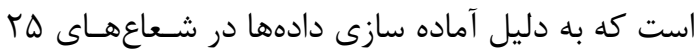

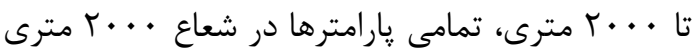
از منطقه مطالعاتى به نمايش در آمدهاند.

$$
\text { م اربرى اراضى }
$$

بلمنظور ارزيابى اثرات كـاربرى زمـين بـر روى ميـزان

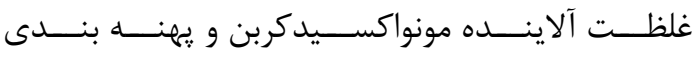
اين آلاينده، نقشه كاربرى اراضى منطقه مطالعاتى، مورد مونو بندي

\footnotetext{
${ }^{1}$ Grubb's test

${ }^{2}$ Kolmogorov-Smirnov
}

بــراى :ــايش دادههـاى جمـعـآورى شـده و اطمينـان از

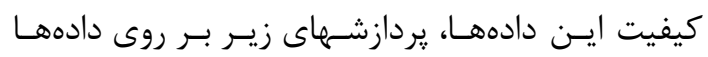

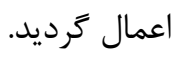
• حذف اثر دمـا: در ابتــدا اثـر دمـا بــر روى ميـزان

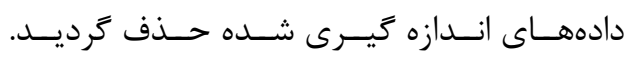

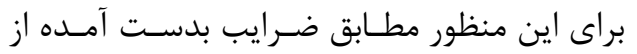

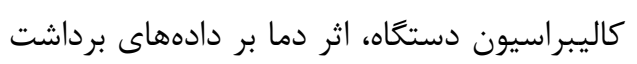
شده حذف كرديد.

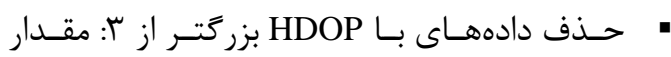

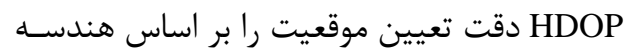
مـاهوارههـاى GPS مشـخص مسىنمايـد. مقــادير

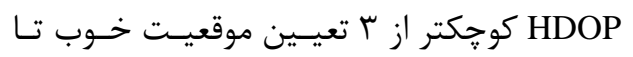

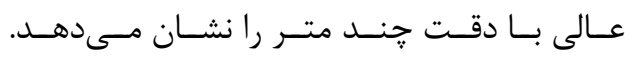

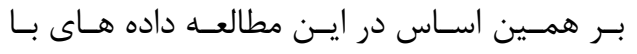

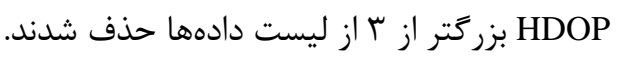

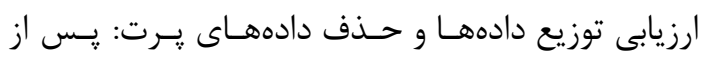

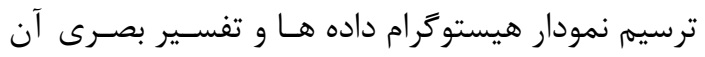

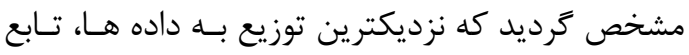

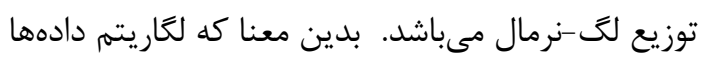

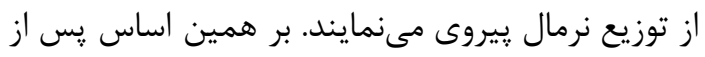




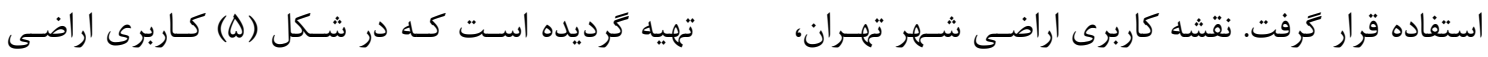

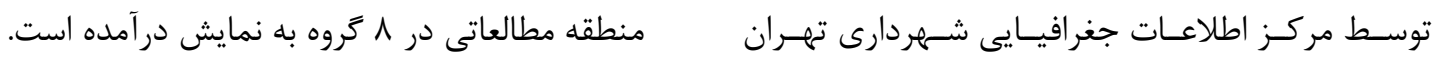

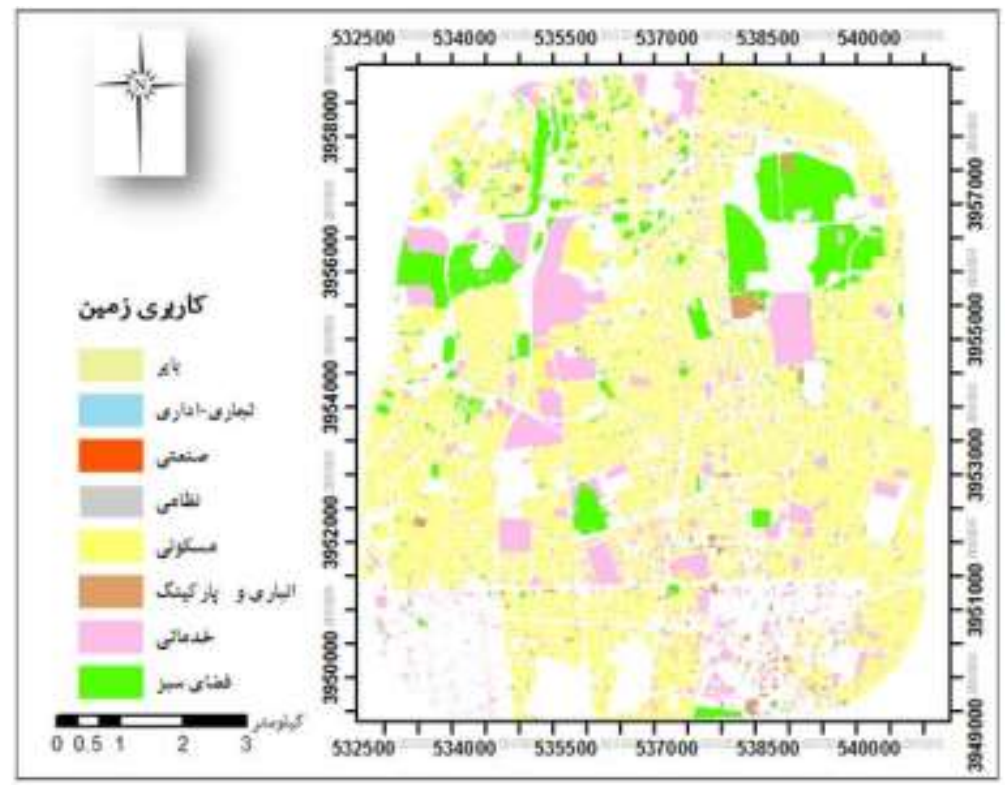

شكل ه : نقشه كاربرى اراضى منطقه مطالعاتى

$$
\text { در مدل وارد گرديد. }
$$

م حجم ترافيك

يكى از متغيرهاى مهرم در مطالعات آلودگى هوا، يـارامتر

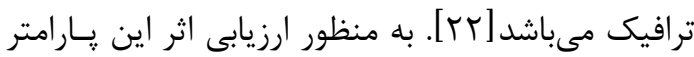
بايد حجم همسنَ سوارى در هريـك از معـابر منطقــه

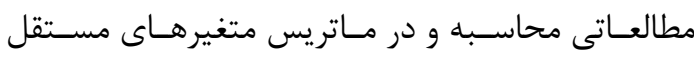

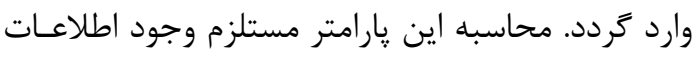

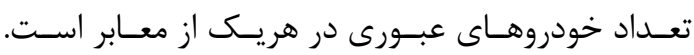

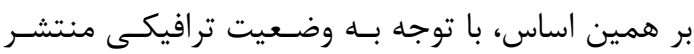

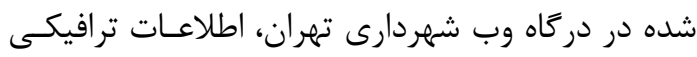

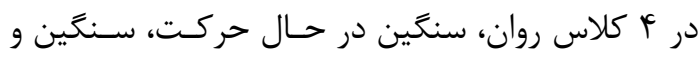

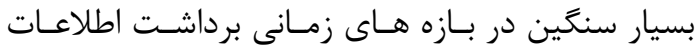

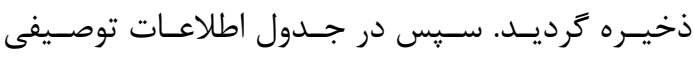

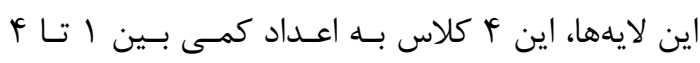

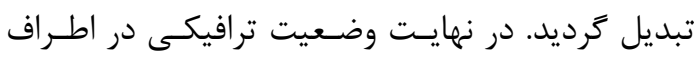

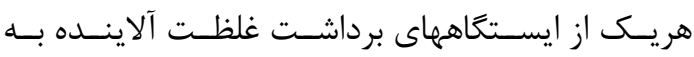

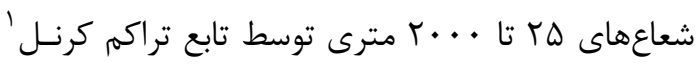

\footnotetext{
${ }^{1}$ Kernel Density
}

بهمنظور ارزيابى اثرات كاربرى اراضى بر غلظت آلاينـده

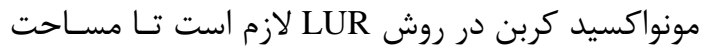
هريك از كاربرى ها در اطراف نقاطى كه غلظت آلاينده اندازه گيرى شده است محاسبه گردد و بهعنوان گيارامتر مستقل در مدل مورد استفاده قرار گيرند. براى حصـول

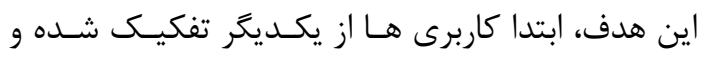

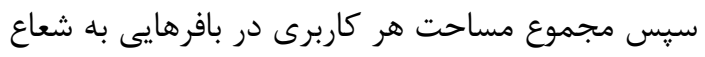

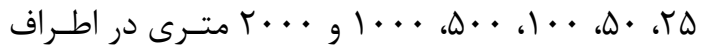

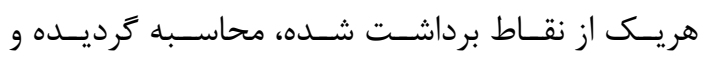
وارد مدل گرديدهاند. م جمعيت

با توجه به نقش جمعيتهاى ساكن در يك منطقـه، در توليد و تجمع آلاينده هاى شهرى، جمعيت نيز به عنوان

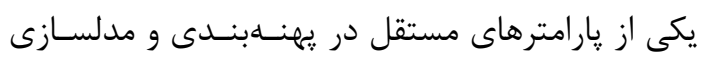

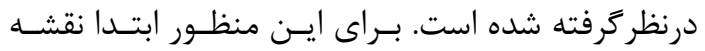
بلوكهاى جمعيتى شهر تهران از مركز فاواى شهردارى

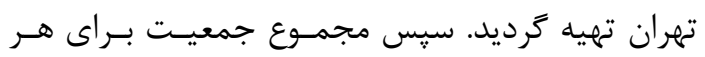

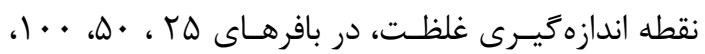

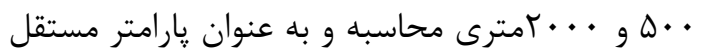


محبوس گرديده و راهى براى خروج به لايههاى بـالايى ي ريدا نخواهند كرد.

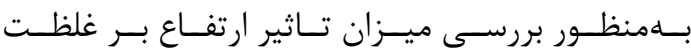

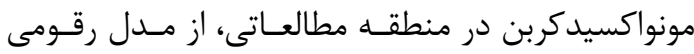

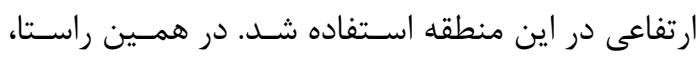

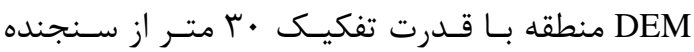

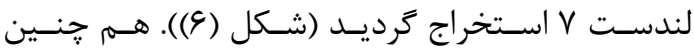

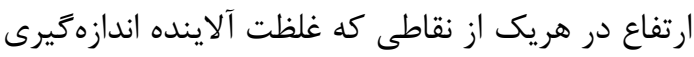

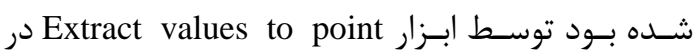

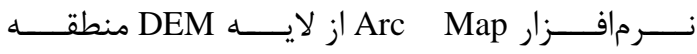
استخراج كرديده است.

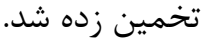

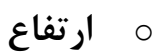

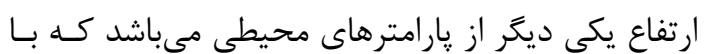

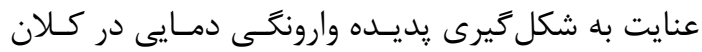

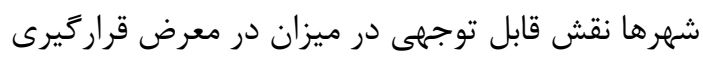

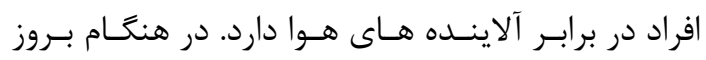

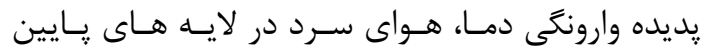

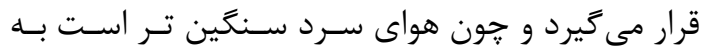

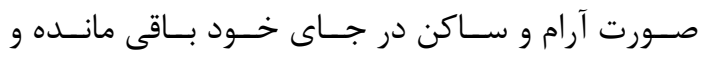
مانع خروج آلاينده ها به لايههاى گرم بالاتر مسى دَردد.

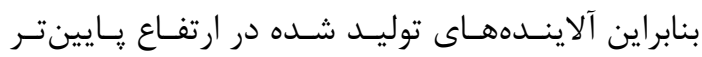

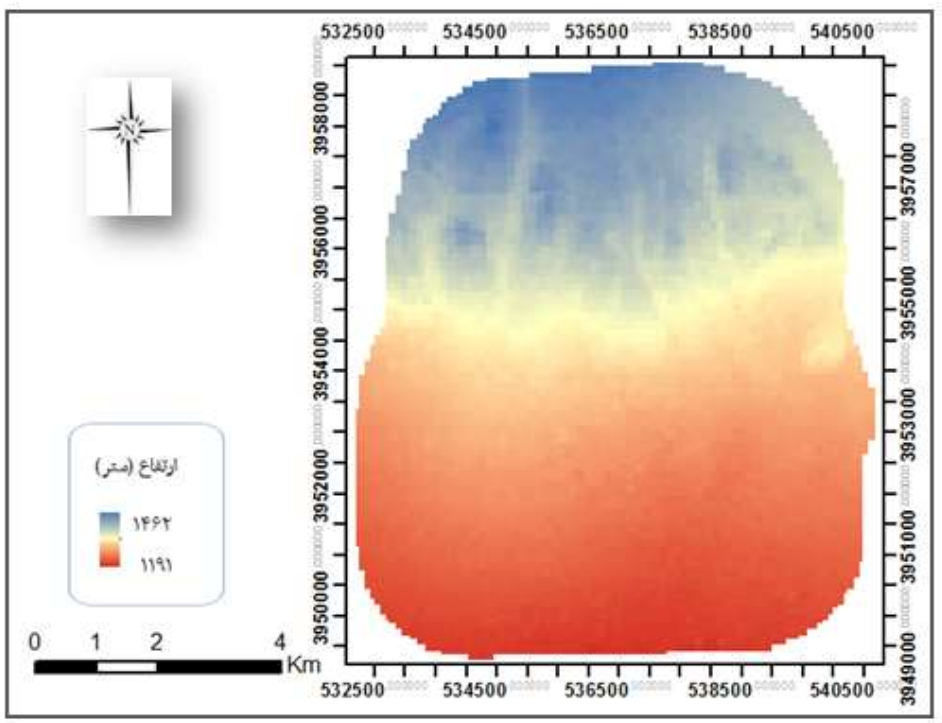

شكل 9 : مدل رقومى ارتفاعى منطقه مطالعاتى

يارامترهاى مستقل اين مطالعه حذف شده است.

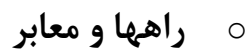

راهها و معابر شهر تهران، به دليل عبور و مـرور وسـائل نقليه متعدد يكى از مكانهاى اصلى تجمع آلاينـده هــا

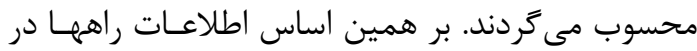
مدلسازى اين تحقيق در نظر كرفته شده است. اطلاعات

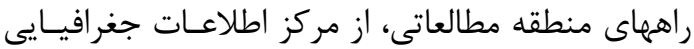
شهر تهران بدست آمد و در سه زير تروه تندراه شهرى،

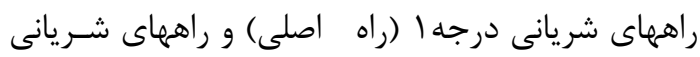

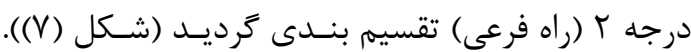

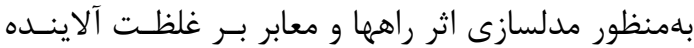

م دما و رطوبت

دما و رطوبت نيز از جمله عوامل محيطى مىباشند كـهـ

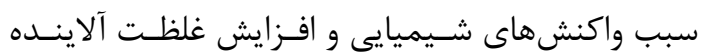
هاى هوا در محيطهاى شهرى مىشوند. مطالعـات اوكى الـى

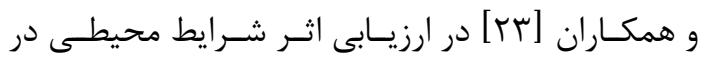

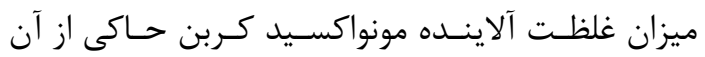

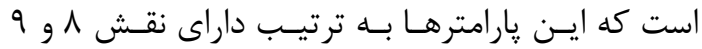
درصدى مىباشند. از ديكر سو به دليل يِيجيـدكى تهـاى

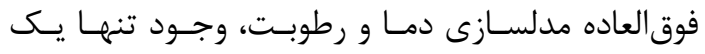
ايستكاه سينويتيك در منطقه مطالعـاتى، مدلسـازى آن آن را غير ممكن مىنمايد. از اين رو، اين بارامترها از ليست 


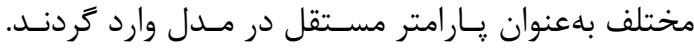

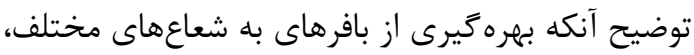

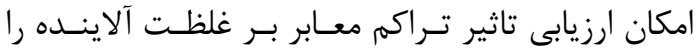

توسط روش ركرسيون كاربرى اراضى فراهم مى آورد.
مونواكسيد كـربن در منطقــه مطالعـاتى مجمـوع طـول

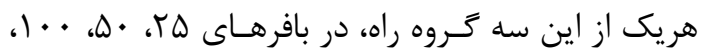

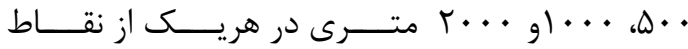

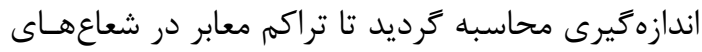

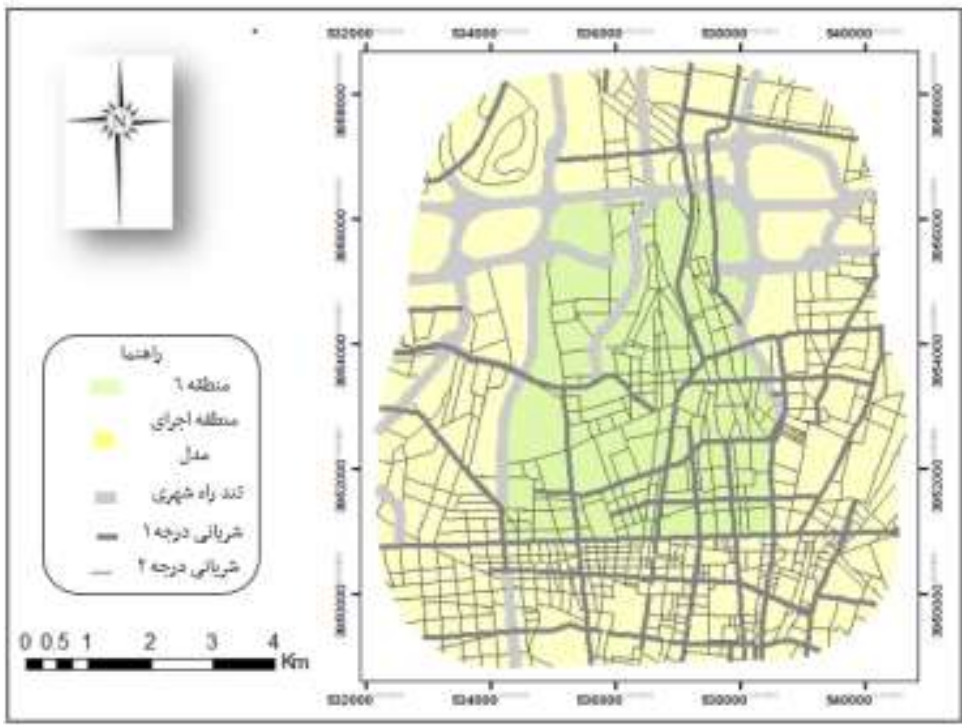

شكل V : نقشه معابر و راههاى منطقه مطالعاتى

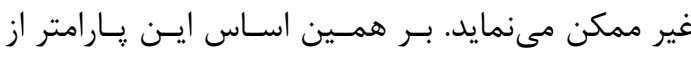
ليست پارامترهاى مستقل اين مطالعه حذف شده است.

$$
\text { F }
$$

براى ساخت مدل ركرسيونى در اين تحقيق، از الكوريته

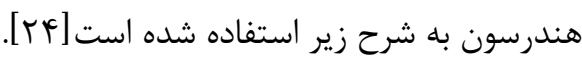

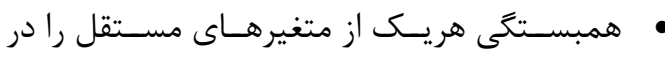

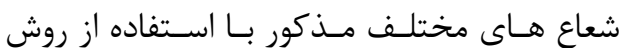

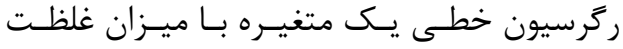

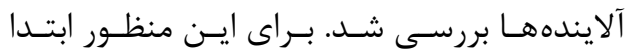
مقادير هريك از يارامترهاى محيطى در نقاطى كه اطلاعات غلظت آلاينده جمع آورى كرديده بودند

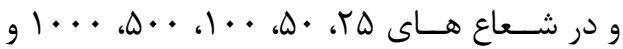

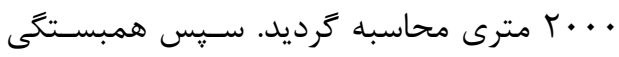
اين مقادير به عنوان يارامتر مستقل مدل و مقادير

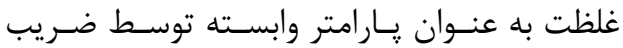
همبستخى يُرسون بدست آمد. ميـانكَين مقــادير

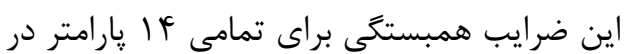

\section{o سرعت و جهت باد}

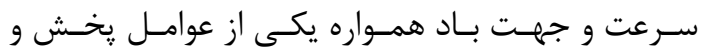

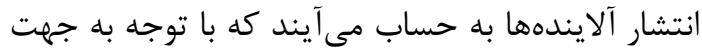
وزش مى توانند داراى نقش مثبت يا منفى در كاهش يـا

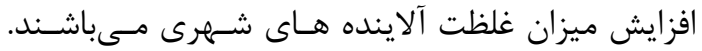

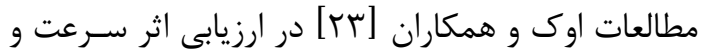

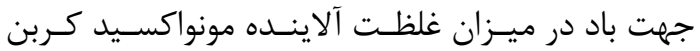

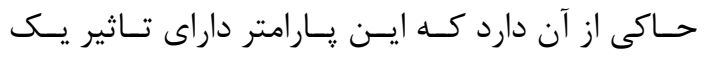

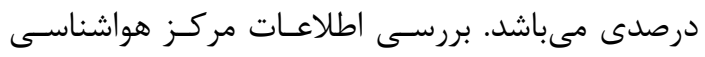
ايستخاه سينويتيك زئوفيزيك (تنها ايستخاه سينويتيك

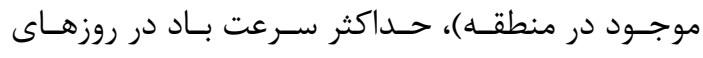

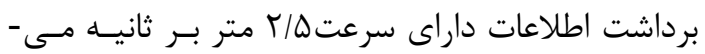
باشد. بنابراين با عنايت با مطالعـه مــذكور شـايد بتـوان

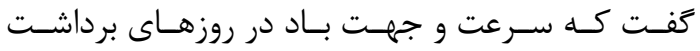

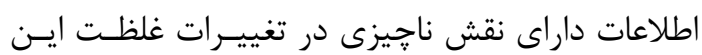

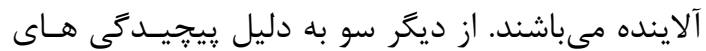
فوق العـاده مدلسـازى بـاد، وجـود تنهـا يـك ايسـتكاه

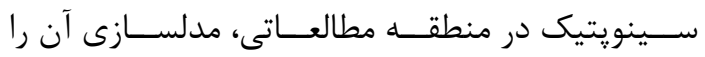


ع شعاع در جدول (1) نمايش داده شده است.

جدولا: ميانكين ضرايب همبستكى ميان غلظت آلاينده و بارامترهاى مستقل در شعاع هاى مختلف براى دو دوره زمانى

\begin{tabular}{|c|c|c|c|c|c|c|c|c|c|c|c|c|c|c|}
\hline $\overrightarrow{\frac{j}{3}}$ & 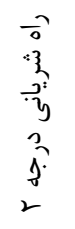 & 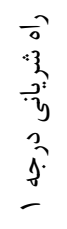 & $\begin{array}{l}3 \\
3 \\
0 \\
3 \\
3 \\
3 \\
y\end{array}$ & $\frac{: 2}{\bar{y}^{2}}$ & $\xi$ & $\overrightarrow{2}$ & $\begin{array}{c}\overline{3} \\
\overline{3} \\
3 \\
3 \\
3 \\
3 \\
\vdots 3 \\
3 \\
3\end{array}$ & ? & 琞 & $\begin{array}{l}\frac{3}{3} \\
\frac{y}{3} \\
\frac{3}{y}\end{array}$ & $\begin{array}{l}3 \\
3 \\
3 \\
3\end{array}$ & $\begin{array}{l}: 3 \\
y \\
y \\
3 \\
3\end{array}$ & 亲 & يֶ) \\
\hline & $\cdot / l F$ & $\cdot / / V$ & $\cdot 1 \cdot \Delta$ & $\cdot / r V$ & .11 & $\cdot / \cdot$ & .119 &.$/ \cdot r$ & $\cdot / \cdot r$ & .1 .9 & $\cdot|r|$ &.$- / .1$ & $\cdot / 1 r$ & $r \Delta$ \\
\hline &.$/ 4 \varphi$ & 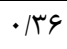 &.$/ K 4$ & $\cdot / V A$ & $\cdot \pi \Lambda$ & .1 .1 & .149 & 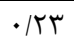 & $\cdot / \cdot r$ & $\cdot / F^{f}$ & .111 &.$- / \cdot r$ & $\cdot / K F$ & a. \\
\hline & .199 & . 199 & $\cdot / V F$ & .119 & $\cdot / N 1$ &.$/ 1 Y$ & $\cdot|\Delta|$ & .111 & $\because$ & $\cdot / r V$ & $\cdot|\pi|$ & $-\frac{R}{-}$ & $\cdot / 4 \Delta$ & $1 \ldots$ \\
\hline & $\cdot / V F$ & | & $\cdot 109$ & $\cdot|\Lambda|$ & .191 &.$/ 14$ & .191 & $\cdot|4|$ & $\because 1$ & . & . & $-\cdot|\lambda|$ &.$|9|$ & $\Delta \cdots$ \\
\hline & r & $\cdot|v|$ & .194 & $\cdot / N T$ &.$/ \mu F$ & $\cdot / \cdot 1$ & $\cdot \mid \Delta \Lambda$ & $\cdot / V F^{F}$ & $\cdot / \cdot V$ & $\cdot|\pi|$ & .148 & -0 T & r & $1 \ldots$ \\
\hline & $\cdot / \pi \wedge$ & צז/. & . IVS & . & $\cdot / N T$ &.$/ . r$ &.$/ T r$ & 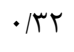 &.$/ 1 f^{f}$ & $\cdot / \cdot \Lambda$ &.$/ 49$ & $-\cdot|r|$ & .1 .9 & $r \ldots$ \\
\hline
\end{tabular}

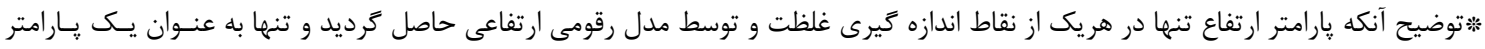
مستقل در مدلسازى وارد كرديد.

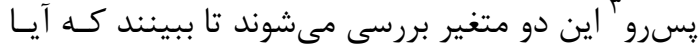

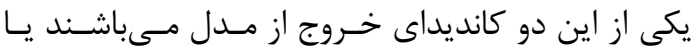

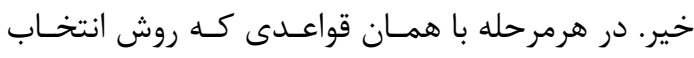

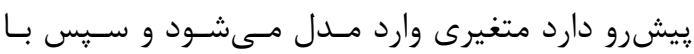
قواعد روش حذف يس رو، كليه متغيرهايى كه تـاكنون

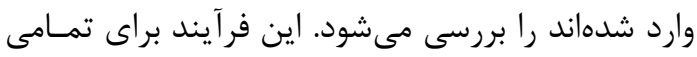

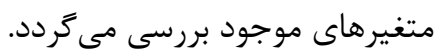

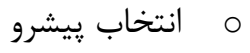

فرض اوليه اين انتخاب اين است كه هـيجيج متغيـرى بــــ

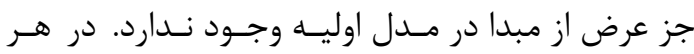

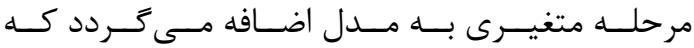

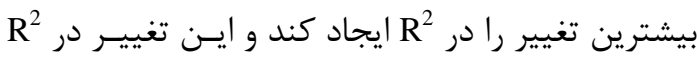

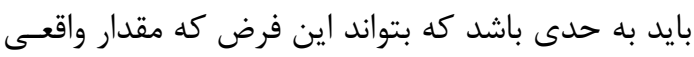

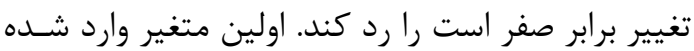
به مدل، متغيرى است كه داراى بيشترين همبستخى با

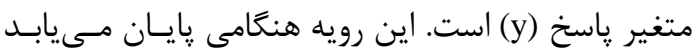

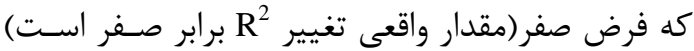

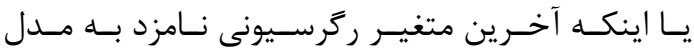

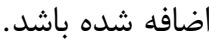

\footnotetext{
${ }^{3}$ Backward Elimination
}

كام هاى آتى ييادهسازى روش ركرسيون كاربرى اراضى به شرح زير مىباشد.

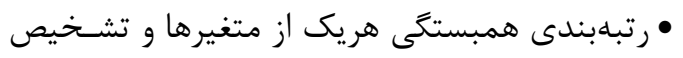

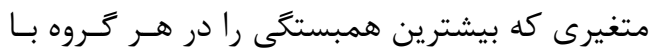
ميزان غلظت آلاينده دارد.

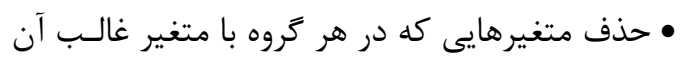

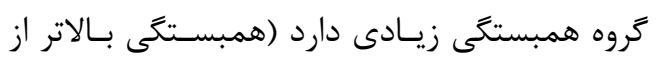

•واردكردن متغيرهاى باقىمانده در مدل ركرسيونى إنى

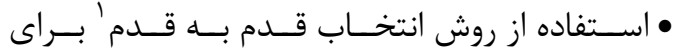
تعيين مدل نهايى (توضـيحات كامـل ايـن روش در

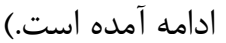
م انتخاب قدم به قدم

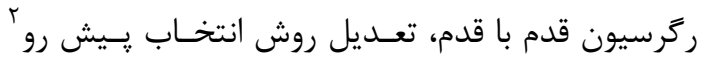

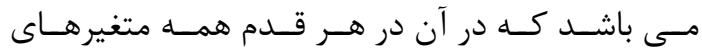

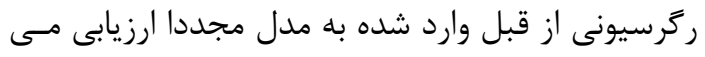

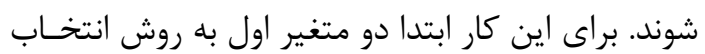

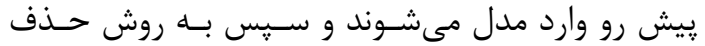

${ }^{1}$ Stepwise Selection

${ }^{2}$ Forward Selection 
غلظتهاى مشاهده شده، مقادير ريشبينى شده و Sobs انحراف معيـار اسـتاندارد

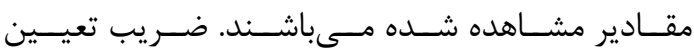

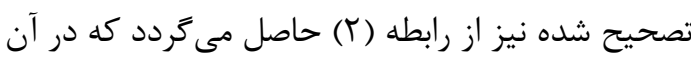

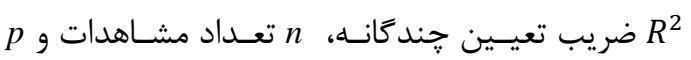
تعداد پارامتر در مدل است. $R_{a d j}^{2}=1-\frac{1-n}{n-p} *\left(1-R^{2}\right)$

(r) رابطه

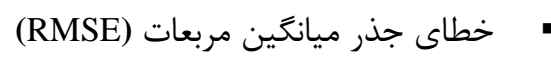

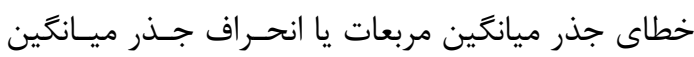

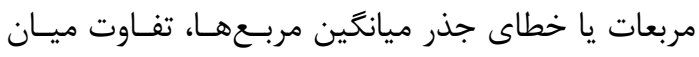

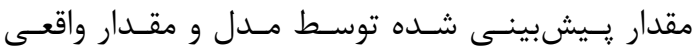

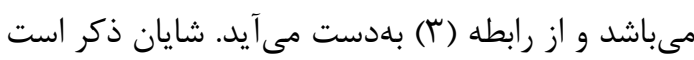

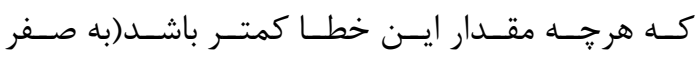
نزديكتر باشد) خطاى مدل در برآورد كمتر بوده است. $R M S E=\sqrt{\frac{1}{N} \sum_{i=1}^{N}\left(P_{i}-O_{i}\right)^{2}}$

رابطه (r)

كه i i مين غلظت رِيشبينى شده،

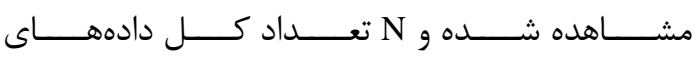

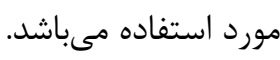

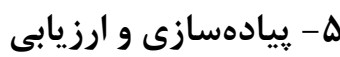

بامنظور يههنه بندى غلظت آلاينده مونواكسيد كربن در

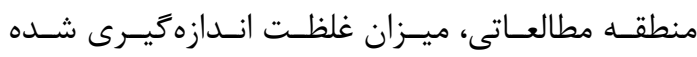

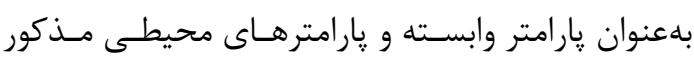

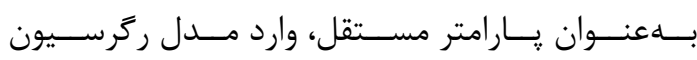

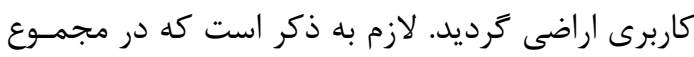

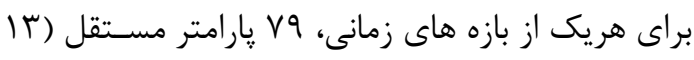

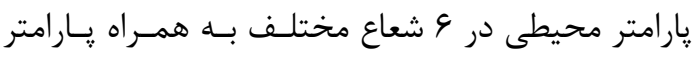
ارتفاع) محاسبه شد. سيس بهترين ساختمان رگرسيون

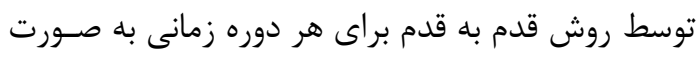

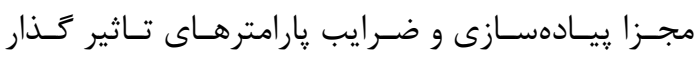

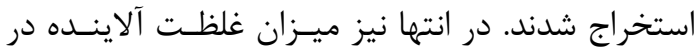

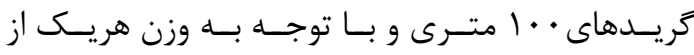

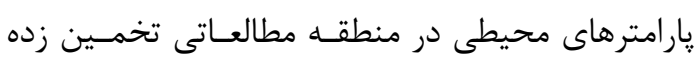

0

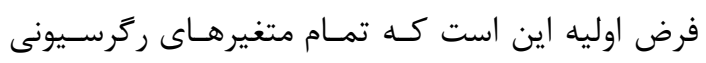

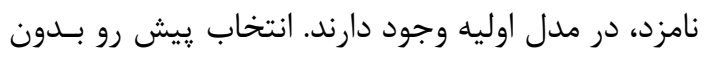

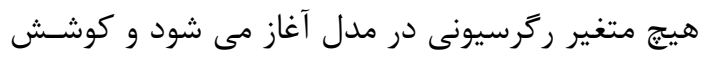
مى شود تا وصول به يك مدل مناسب متغيرها به مـدل

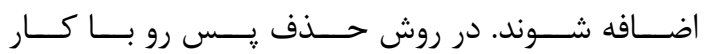
در جهت مخالف سعى بر اين است مدل خوبى بهدست

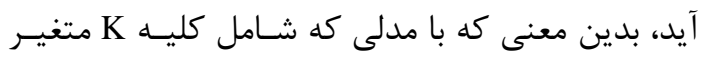

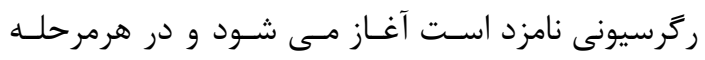

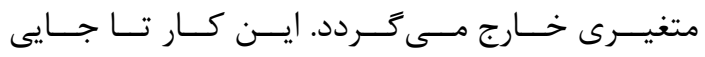

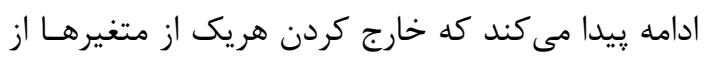
مدل، تغيير معنادارى در R2 ايجاد كند.

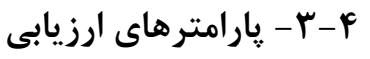

يارامترهاى ارزيابى متعددى براى ارزيابى و اعتبارسنجى روشهاى آمارى نظير ركرسيون وجـود دارنــد. در ايسن

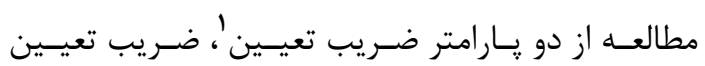
تعديل شده و خطاى جذر ميانخين مربعات ' كه با علائم

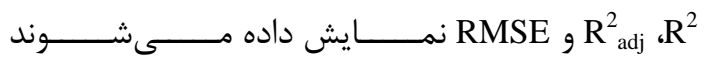
استفاده شده است.

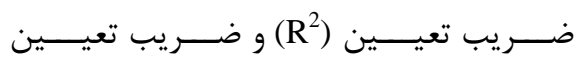
تعديل شده

ايسن ضــريب بـهمنظــور انـدازهزيــرى ميـزان اعتمــاد و

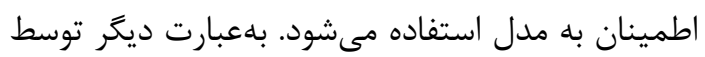
اين ضريب مىتوان نيكويى برازش را برآورد نمود. مقدار

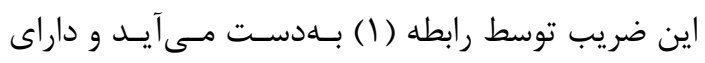
مقادير در بـازه [0,1] مسىباشــد و مقــدار بـالاتر بيـانكر

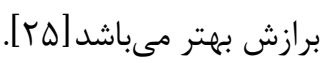
$R^{2}=\left(\frac{\sum_{i=1}^{n}\left(P_{i}-\bar{P}\right)\left(O_{i}-\bar{O}\right)}{n * S_{\text {pred }} * S_{\text {obs }}}\right)^{2} \quad$ رابطه (1) در اين رابطـه ميانگين غلظتهاى يـيشبينى شده،

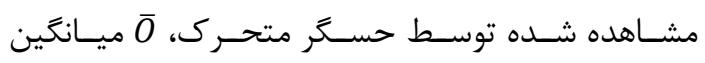

${ }^{1}$ Coefficient of determination

${ }^{2}$ Root Mean Square Error 


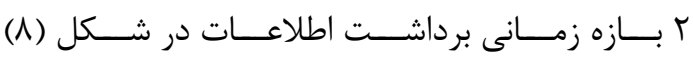
به نمايش در آمدهاست.

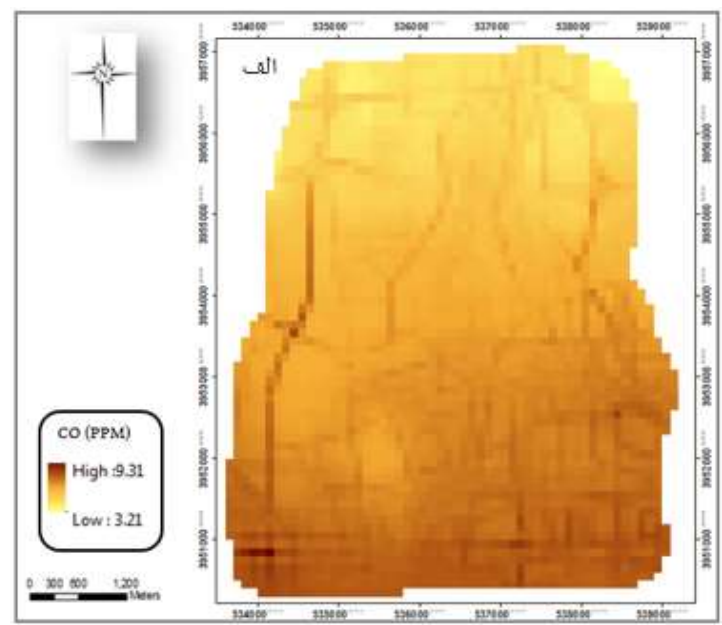

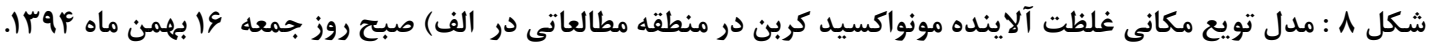

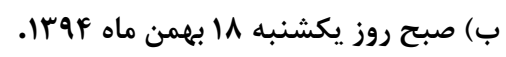

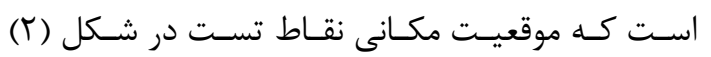

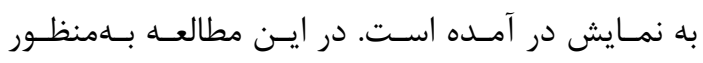

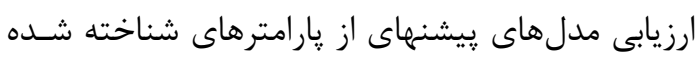

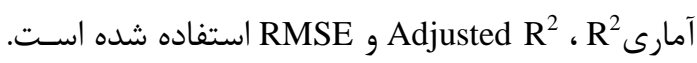

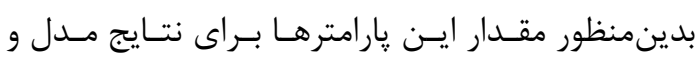

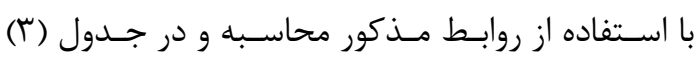
نمايش داده شده است. جدول r: رتبه بندى بارامترهاى موثر در غلظت آلاينده

\begin{tabular}{|c|c|c|}
\hline \multicolumn{3}{|c|}{ مونواكسيد كربن } \\
\hline شديانكين ضريب استاندارد & يارامتر & 3 \\
\hline •/DT & ترافيك & 1 \\
\hline . Mt & تندراه شهرى & $r$ \\
\hline$\cdot / 4 q$ & راه شريانى درجه r & r \\
\hline$-\cdot / 48$ & فضاى سبز & f \\
\hline$\cdot|r|$ & راه شريانى درجه 1 & $\Delta$ \\
\hline-.119 & ارتفاع & 9 \\
\hline $.1 \cdot 9$ & خدماتى & V \\
\hline$\cdot 1 \cdot 1$ & مسكونى & $\wedge$ \\
\hline$\cdot 1 \cdot \Delta$ & تراكم جمعيت & 9 \\
\hline
\end{tabular}

شناسايى يارامترهاى موثر و رتبــابنـدى تـاثير آنهـا در

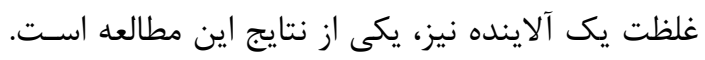

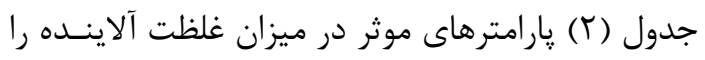

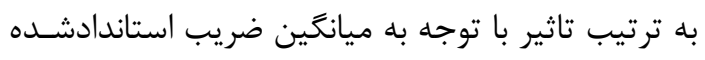

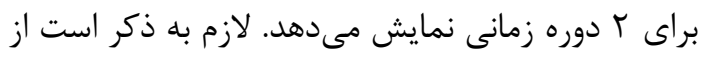

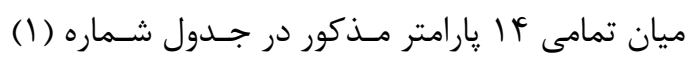
تنها 9 هارامتر محيطى (فارغ از شعاعهـائى كـهـ مقــادير

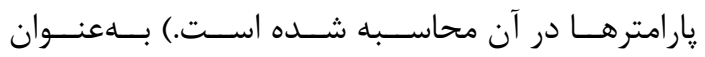
پارامترهاى اثر كذار بر غلظت آلاينده مونواكسيد كـربن

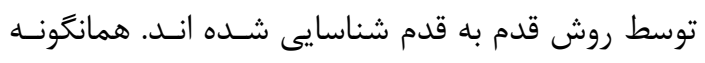

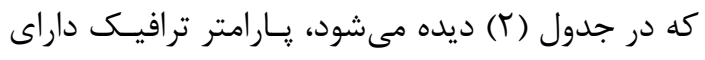

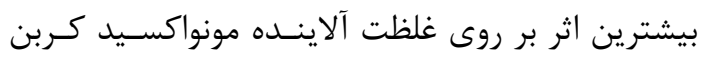

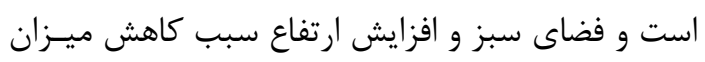
غلظت اندازهيرى شده آلاينده كرديده است.

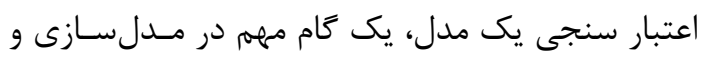

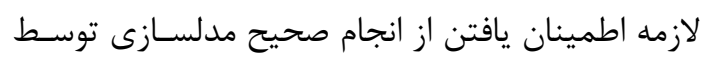

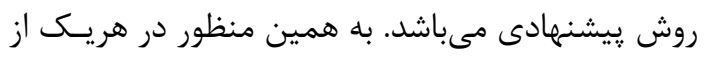

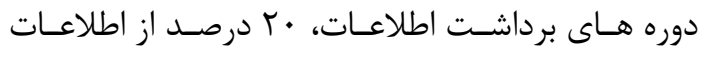

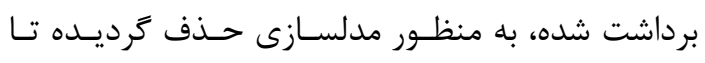

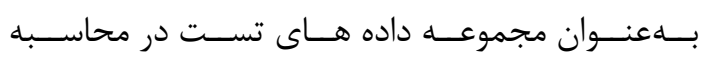

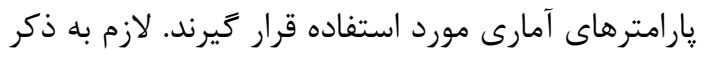


مناسب ( $)$

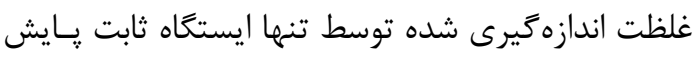

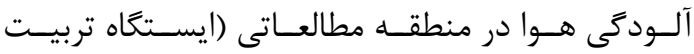

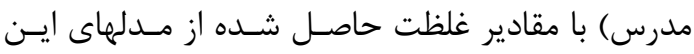

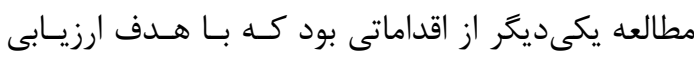
دقت اين يزوهش صورت يذيرفت. جدول (\&) اين مقاير

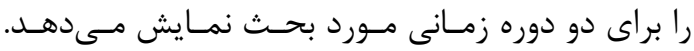
همانكونه كه در اين جدول مشـاهده مسى تحردد مقــادير

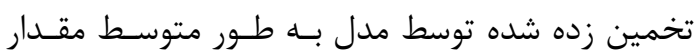

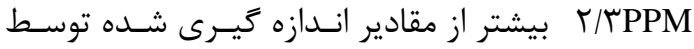

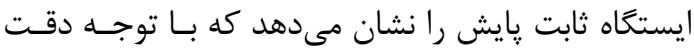
مدل مكانى توسعه داده شده قابل قبول مىباشد.
جدول سب: نتايج حاصل از ارزيابى مدل

\begin{tabular}{|c|c|c|c|}
\hline RMSE & $\mathbf{R}^{2}{ }_{\text {adj }}$ & $\mathbf{R}^{2}$ & دوره زمانى \\
\hline$F / \cdot r$ & . IOT & $\cdot|9|$ & 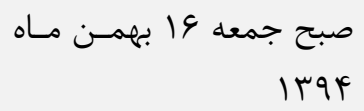 \\
\hline$\Delta / \Delta V$ & $\cdot / 4 q$ & $\cdot|\Delta|^{F}$ & | صبح يكشنبه |1| بهمن ماه \\
\hline
\end{tabular}

روش ركرسـيون كـاربرى اراضسى يـك روش آمـارى در

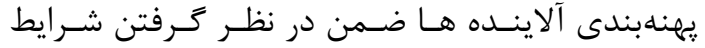

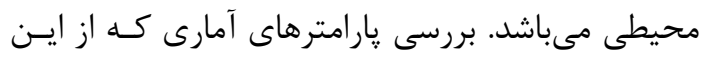

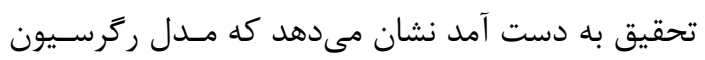

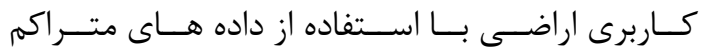

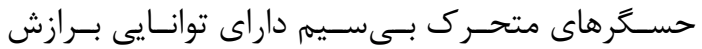

جدول F: غلظت آلاينده مونواكسيد كربن در ايستگًاه ثابت تربيت مدرس و مقادير حاصل شده از مدل توسعه داده شده

\begin{tabular}{|c|c|c|}
\hline ميانگين غلظت آلاينده مونواكسيد كربن حاصل شده از موقعيت مكانى ايستخاه تربيت مدرس (PPM) & 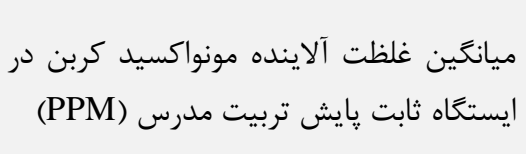 & \\
\hline$\Delta / V$ & r & صبح جمعه \\
\hline$\Delta / 9$ & $r / 9$ & صبح يكشنبه \\
\hline
\end{tabular}

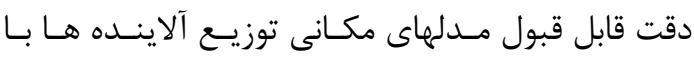
استفاده از اين نوع حسكرها مىباشد.

رويههاى بـهـدست آمــه حساكى از آن دارد كـهـ تـراكم غلظت در قسمت هاى جنوبى منطقـهـ مطالعـاتى بـالاتر

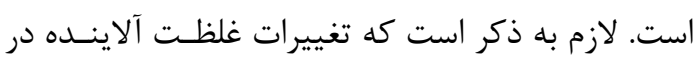
دو بازه زمانى برداشت اطلاعات، تفاوت جشم كيرى را با بال

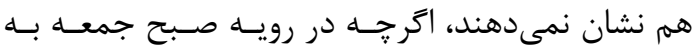

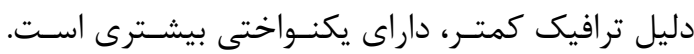
يكى ديخر از نتايج جالب توجه اين مطالعه، بـالاتربودن

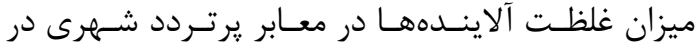

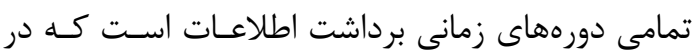

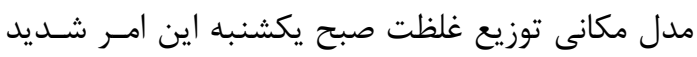
تر كرديده است. شايان ذكر است كه افزايش غلظـت در معابر شهرى به نوعى بيانكر اين موضـوع مسىباشـد كـهـ

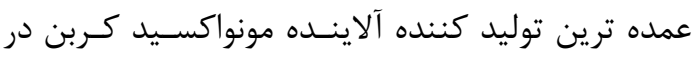

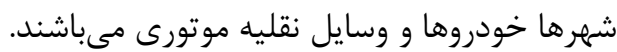

رشد و گسترش تكنولوزى در دهه اخير منجر به ظهـور

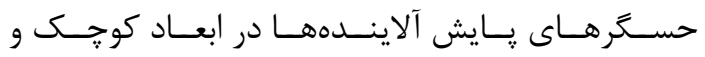
قابل حمل با تكنولوزىهاى متنوعى كرديده كـهـ امكـان يايش ميزان آلاينده ها را در هر مكان و زمانى براى مـاس فراهم مىنمايند. در واقع با استفاده از اين نوع حسكرها

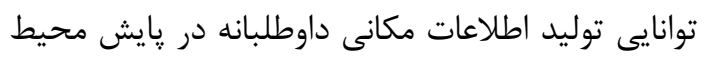
هاى شهرى با تغييرات جشمخيرى روبرو گرديد. بهطسـور

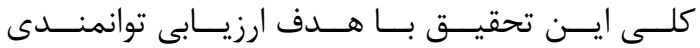

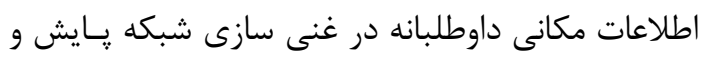

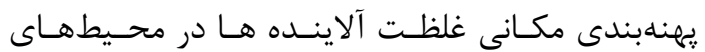

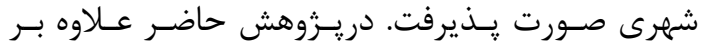

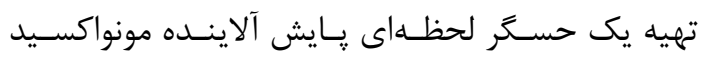

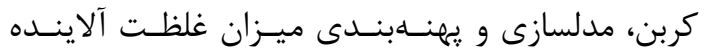

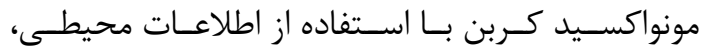
در منطقه مطالعاتى صورت يذيرفت كه نتـايج حـاكى از 


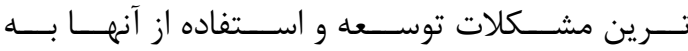

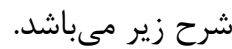

$$
\begin{aligned}
& \text { هيازمند يردازش هاى بعدى بـراى تصـحيح اثـرات } \\
& \text { دما و رطوبت }
\end{aligned}
$$

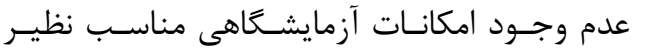

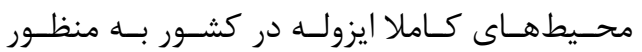

$$
\begin{aligned}
& \text { كاليبراسيون دقيق اين نوع حسگرها }
\end{aligned}
$$

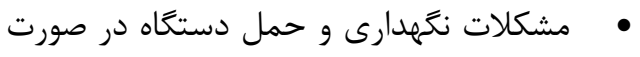

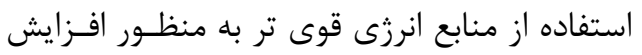

$$
\begin{aligned}
& \text { بازه زمانى برداشت اطلاعات. }
\end{aligned}
$$

[1] R. Piedrahita, Y. Xiang, N. Masson, J. Ortega, A. Collier, Y. Jiang, K. Li, R. Dick, Q. Lv, and M. Hannigan, "The next generation of low-cost personal air quality sensors for quantitative exposure monitoring," Atmospheric Measurement Techniques, vol. 7, pp. 3325-3336, 2014.

[2] A. Turner, Introduction to neogeography: " O'Reilly Media, Inc.", 2006.

[3] J. Howe, "The rise of crowdsourcing," Wired magazine, vol. 14, pp. 1-4, 2006.

[4] L. J. Rouse, S. J. Bergeron, and T. M. Harris, "Participating in the geospatial web: collaborative mapping, social networks and participatory GIS," in The Geospatial Web, ed: Springer, 2009, pp. 153-158.

[5] R. Chambers, "Participatory mapping and geographic information systems: whose map? Who is empowered and who disempowered? Who gains and who loses?," The Electronic Journal of Information Systems in Developing Countries, vol. 25, 2006.

[6] M. F. Goodchild, "Citizens as sensors: the world of volunteered geography," GeoJournal, vol. 69, pp. 211-221, 2007.

[7] M. Zook, M. Graham, T. Shelton, and S. Gorman, "Volunteered geographic

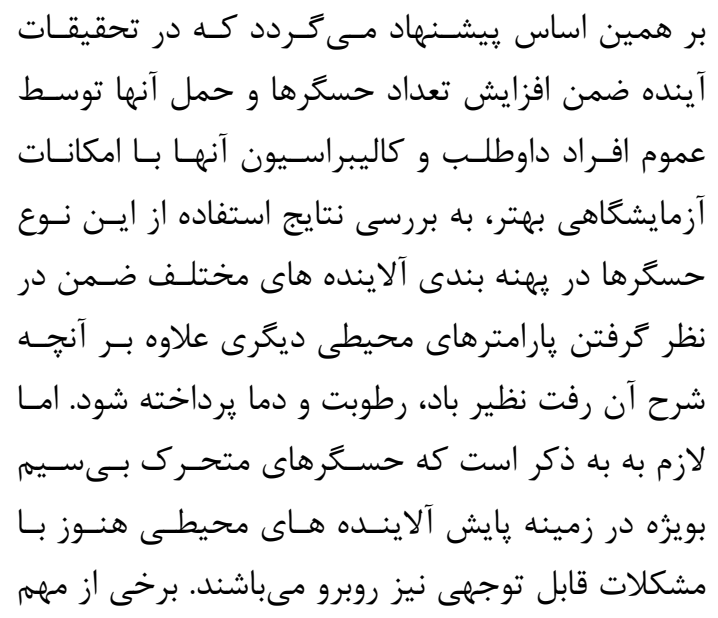

\section{مراجع}

information and crowdsourcing disaster relief: a case study of the Haitian earthquake," World Medical \& Health Policy, vol. 2, pp. 7-33, 2010.

[8] J. P. Lynch and K. J. Loh, "A summary review of wireless sensors and sensor networks for structural health monitoring," Shock and Vibration Digest, vol. 38, pp. 91130, 2006.

[9] S. Soleimani, E. Keshtehgar, and M. Malek, "Ubisound: Design a User Generated Model in Ubiquitous Geospatial Information Environment for Sound Mapping," The International Archives of Photogrammetry, Remote Sensing and Spatial Information Sciences, vol. 40, p. 243, 2014.

[10]M. Mead, O. Popoola, G. Stewart, P. Landshoff, M. Calleja, M. Hayes, J. Baldovi, M. McLeod, T. Hodgson, and J. Dicks, "The use of electrochemical sensors for monitoring urban air quality in low-cost, high-density networks," Atmospheric Environment, vol. 70, pp. 186-203, 2013.

[11]E. Kanjo, "Noisespy: A real-time mobile phone platform for urban noise monitoring and mapping," Mobile Networks and Applications, vol. 15, pp. 562-574, 2010.

[12]M. Tomczak, "Spatial interpolation and its 
uncertainty using automated anisotropic inverse distance weighting (IDW)-crossvalidation/jackknife approach," Journal of Geographic Information and Decision Analysis, vol. 2, pp. 18-30, 1998.

[13]F. Nyberg, P. Gustavsson, L. Järup, T. Bellander, N. Berglind, R. Jakobsson, and G. Pershagen, "Urban air pollution and lung cancer in Stockholm," Epidemiology, vol. 11, pp. 487-495, 2000.

[14] G. W. Fisher, B. W. L. Graham, and M. J. Bell, Design of a National Ambient Air Quality Monitoring Network for New Zealand: A NIWA/ESR Study Prepared for the New Zealand Ministry for the Environment: NIWA, 1995.

[15] R. Honicky, E. A. Brewer, E. Paulos, and R. White, "N-smarts: networked suite of mobile atmospheric real-time sensors," in Proceedings of the second ACM SIGCOMM workshop on Networked systems for developing regions, pp25-30., , 2008.

[16] S. Choi, N. Kim, H. Cha, and R. Ha, "Micro sensor node for air pollutant monitoring: Hardware and software issues," Sensors, vol. 9, pp. 7970-7987, 2009.

[17]P. Dutta, P. M. Aoki, N. Kumar, A. Mainwaring, C. Myers, W. Willett, and A. Woodruff, "Common sense: participatory urban sensing using a network of handheld air quality monitors," in Proceedings of the 7th ACM conference on embedded networked sensor systems, pp349-350., 2009.

[18] S. Kim, E. Paulos, and M. D. Gross, "WearAir: expressive t-shirts for air quality sensing," in Proceedings of the fourth international conference on Tangible, embedded, and embodied interaction, pp 295-296., , 2010.

[19]G. Hoek, R. Beelen, K. De Hoogh, D. Vienneau, J. Gulliver, P. Fischer, and D. Briggs, "A review of land-use regression models to assess spatial variation of outdoor air pollution," Atmospheric environment, vol. 42, pp. 7561-7578, 2008.

[20] D. Briggs, A. Aaheim, C. Dore, G. Hoek, M. Petrakis, and G. Shaddick, "Air pollution modelling for support to policy on health and environmental risks in Europe. Final Report Section 6. Imperial College, London (2005)," EVK2-2002-00176. Available from: http://www. apmosphere. org.

[21] T. Larson, S. B. Henderson, and M. Brauer, "Mobile monitoring of particle light absorption coefficient in an urban area as a basis for land use regression," Environmental science \& technology, vol. 43, pp. 4672-4678, 2009

[22] J. J. Kim, S. Smorodinsky, M. Lipsett, B. C. Singer, A. T. Hodgson, and B. Ostro, "Traffic-related air pollution near busy roads: the East Bay Children's Respiratory Health Study," American journal of respiratory and critical care medicine, vol. 170, pp. 520-526, 2004.

[23] S. Ocak and F. S. Turalioglu, "Effect of meteorology on the atmospheric concentrations of traffic-related pollutants in Erzurum, Turkey," J. Int. Environmental Application \& Science, vol. 3, pp. 325-335, 2008.

[24] S. B. Henderson, B. Beckerman, M. Jerrett, and M. Brauer, "Application of land use regression to estimate long-term concentrations of traffic-related nitrogen oxides and fine particulate matter," Environmental science \& technology, vol. 41, pp. 2422-2428, 2007.

[25]H. A. Hamida, A. S. Yahayab, N. A. Ramlib, and A. Z. Ul-Saufie, "Performance of parameter estimator for the two-parameter and three-parameter gamma distribution in PM10 data modelling," International Journal of Engineering and Technology, vol. 2, pp. 637-643, 2012. 


\title{
Enrichment of Air Quality Monitoring with mobile Sensors for Spatial Modelling of Pollutants (case study: CO in Tehran)
}

\author{
Manouchehr Kheradmandi ${ }^{1}$, Rahim Ali Abbaspour ${ }^{* 2}$ \\ 1- MSc student of GIS, School of Surveying and Geospatial Engineering. College of Engineering, University of Tehran. \\ 2- Assistant professor, School of Surveying and Geospatial Engineering, College of Engineering, University of Tehran.
}

\begin{abstract}
By developing wireless mobile sensors, volunteered geographic information production and social cooperating increase, urban monitoring witnessed a considerable change. On the other hand, air pollution become one of the most important environmental challenge of Tehran and tackling it is not possible unless knowing the pollutants and their sources. Accurate investigation of spatial distribution of pollutants in cities requires development of spatial variability models of pollutants. But, high cost of developing and keeping of Air Quality Monitoring Network (AQMN) is one of the biggest problems in front of councils in developing such monitoring stations in cities. In this research, in addition to designing and building a mobile carbon monoxide monitoring system and calibrating it in the lab, data of pollutants concentration in 4 time periods in district 6 of Tehran was collected. Then by using land use regression method the spatial distribution model of this pollutant for the investigated area in each time period was determined. To reach this achievement, different environmental factors such as land use, Roads, elevation and traffic as independent factors and the measured pollutant concentration as dependent factor were applied to the mentioned model. Finally, this research led to provide carbon monoxide pollution maps for the investigated area, which are useful in finding high risk locations. Evaluating the statistical parameters show that in estimating pollutant concentration of different urban districts, the suggested method is practical to some extends.
\end{abstract}

Key words: Volunteered Geographic Information, Wireless mobile air quality sensors, Land use regression, Air pollution map.

Correspondence Address:. School of Surveying and Geospatial Eng., Faculty of Engineering, University of Tehran, Tehran, Iran.

Tel: 09123011255

Email: abaspour@ut.ac.ir 